\title{
Identification of Amino Acid Tethered Triazoles as Potential Antifungal Leads: Appraisal of their Mode of Action
}

\section{Parteek Prasher*}

Department of Chemistry, University of Petroleum and Energy Study, Dehradun, Uttaranchal, India

\begin{abstract}
A new set of compounds containing indole nucleus appended with carefully selected amino acids via a triazole linker are identified. These compounds showed substantial antifungal activities against the BWP17 strain of candida albicans. The preliminary screening of the compounds was done by docking in the active site of lanosterol 14- $\alpha$ demethylase enzyme (pdb ID - 3JUS) with ArgusLab.exe software. Subsequently the screened compounds were subjected to in-vivo antifungal assays. The probable mechanism of action of the test compounds was studied by GC analysis of the membrane metabolites. The compounds with tryptophan and histidine substitution were found to be most effective with MIC80 of $50.2 \mu \mathrm{g} / \mathrm{ml}$ and $78.81 \mu \mathrm{g} / \mathrm{ml}$ respectively. In the fungal cells treated with compound 3b the lanosterol levels were found to increase indicating that lanosterol 14- $\alpha$ demethylase enzyme could be the probable target. Additionally, the R6G influx/efflux assay provided the evidence for the fungicidal properties of the test compounds.
\end{abstract}

Keywords: CA BWP 17- Candida albicans BWP 17; R6G-Rhodamine 6G; Gas chromatography; MIC80-minimum inhibitory concentration for $80 \%$ inhibition

\section{Introduction}

Diseases caused by fungus are one of the major global challenges today. Starting from local infections to systemic mycosis the fungi are causing more deaths compared to malaria and tuberculosis. Yeasts, primarily the Candida albicans species are the most noxious mediators of invasive mycoses predominantly among the immuno compromised patients [1,2]. The pathogenecity and infectiousness of the fungal diseases therefore needs to be checked and regulated.

Various classes of antifungal drugs have been developed till date to counter the menace created by fungal diseases. The polyene antifungals like amphotericin-B, natamycin primarily target ergosterol [3] which helps in maintaining the fungal membrane integrity. These amphiphilic polyenes on interaction with the fungal membrane make it leaky by creating the pores which eventually leads to the membrane disruption and fungal death. The azole antifungal drugs on the other hand target the CYP P450 14-a demethylase enzyme [4] which mediates the biosynthesis of ergosterol from lanosterol. This alters the morphology and physical properties of the fungal membrane by impeding the functioning of the membrane proteins. Another class of antifungals, allylamines [5] target the enzyme squalene epoxidase which mediates the conversion of squalene to squalene-2,3-epoxide. The allylamines like terbinafine leads to the buildup of squalene causing a $\mathrm{pH}$ imbalance in the fungal membrane thereby limiting its growth. The newest class of antifungals, Echinocandins [6] impair the functioning of beta-1,3D-glucan synthase enzyme in fungi by noncompetitive inhibition eventually leading to the cell death. Despite all the efforts the antifungal therapy is still far off the target because of the efflux pumps operating in the fungal membranes [7]. The present work focuses on the design of the compounds chiefly to target the lanosterol 14- $\alpha$ demethylase enzyme present in the fungal membrane. The biological importance of these compounds is already been checked for their anti-inflammatory property by targeting the enzymes 5 -LOX and COX-1/2 enzymes [8]. Interestingly, besides targeting the desired enzyme the compounds were also found to have membrane lysing properties.

The validation of indole moiety and azole nucleus in the antifungal therapeutics for targeting the fungal membrane has been widely acclaimed. The indole nuclei substituted with the carefully selected amino acids via azole linkage has been tested for its antifungal efficacy against the BWP17 strain of candida albicans. The screening of the appropriate amino acids was done by docking the test compounds in the lanosterol 14- $\alpha$ demethylase enzyme (pdb ID - 3JUS) with the help of ArgusLab.exe software. Apart from that, the Lipinski parameters were also calculated for the test compounds theoretically by molinspiration software. From the preliminary investigations, it was observed that the compounds having glycine, tryptophan, histidine, glutamic acid and tyrosine substitution displayed a better docking characteristics in the active site of the enzyme. The hydrophilicity index (ClogP value) for these compounds was also evaluated experimentally by determining the octanol/water partitioning coefficient by the shake flask method and the concentration of analytes was found by quantitative HPLC method. The hydrophilicity index thus obtained was found to be quite similar to that required by the lipinski parameters.

\section{Experimental Section}

\section{Synthesis}

The L-amino acids $(1 \mathrm{mmol})$ were dissolved in $20 \mathrm{ml}$ of DCM in a round bottom flask kept on an ice bath. The mixture was stirred for a few minutes till the solution becomes clear. Activated $\mathrm{K}_{2} \mathrm{CO}_{3}(1.2$ equivalent, activated by storing at $100^{\circ} \mathrm{C}$ overnight) was then added to this solution. Afterwards trifluoromethanesulphonic anhydride $(0.1$ $\mathrm{mmol}$ ) was very carefully added, dropwise to the reaction mixture. On addition, the colour of the reaction mixture immediately changes from colourless to light green. After stirring the contents of reaction mixture

*Corresponding author: Parteek Prasher, Assistant Professor, Department of Chemistry, University of Petroleum and Energy Study, Dehradun, Uttaranchal-248 007, India, Tel: 01352776054; E-mail: parteekprasher4@gmail.com

Received September 19, 2016; Accepted October 05, 2016; Published October 11, 2016

Citation: Prasher P (2016) Identification of Amino Acid Tethered Triazoles as Potential Antifungal Leads: Appraisal of their Mode of Action. Chem Sci J 7: 139. doi: $10.4172 / 2150-3494.1000139$

Copyright: @ 2016 Prasher $P$. This is an open-access article distributed under the terms of the Creative Commons Attribution License, which permits unrestricted use, distribution, and reproduction in any medium, provided the original author and source are credited. 
for 2-3 minutes was added $\mathrm{CuSO}_{4} \cdot 5 \mathrm{H}_{2} \mathrm{O}(2.0 \mathrm{mmol})$ followed by the addition of sodium azide $(1.0 \mathrm{mmol})$. The progress of the reaction was monitored by thin layer chromatography. The reaction completed in about 6-8 hours. After the reaction completion, the reaction mixture was washed with $15 \mathrm{ml}$ of distilled water and the product was extracted by chloroform using a separator funnel. The final product was azide adduct of the amino acid (Compounds i, ii, iii, iv and v; Scheme 1).

3-methylindole (1) was dissolved in $5 \mathrm{ml} \mathrm{DMSO}$ and allowed to stir for a few seconds till a clear solution is obtained. To this solution was added sodiumhydride (1.2 equivalent, washed with dry hexane to remove the paraffin coating). The reaction mixture was now stirred for 3-4 minutes till a visible change in the colour of the reaction mixture is observed. The change in colour corresponds to the generation of anion on the indole nucleus. Furthur, propargyl bromide (1.2 equivalent) was added carefully, dropwise to the reaction mixture. The completion of the reaction was monitored with the help of thin layer chromatography. Reaction completes in 25 minutes to give the product (2). The product (2) was dissolved in 9:1 solution of EtOH: $\mathrm{H}_{2} \mathrm{O}$ to get a clear solution. To this solution was immediately added $0.02 \mathrm{mmol} \mathrm{CuSO}_{4} \cdot 5 \mathrm{H}_{2} \mathrm{O}$. After waiting for 5 minutes, $0.05 \mathrm{mmol}$ sodium ascorbate was added to the reaction mixture and the contents were allowed to stir for 10 minutes.<smiles>NCC(=O)O</smiles>

glycine<smiles>NC(Cc1c[nH]c2ccccc12)C(=O)O</smiles>

D. tryptophan
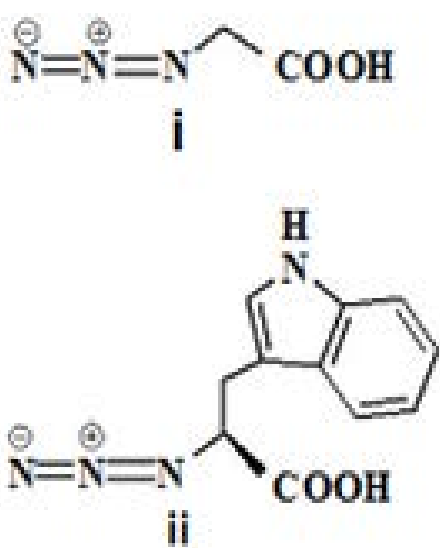<smiles>[N-]=[N+]=NC(Cc1c[nH]nn1)C(=O)O</smiles>

iii<smiles></smiles>

iv<smiles>[N-]=[N+]=NC(Cc1ccc(O)cc1)C(=O)O</smiles>

V

Scheme 1 
Finally, the azidoamino acid obtained in Scheme 1 was added to the reaction mixture. The monitoring of the reaction was done by thin layer chromatography. The reaction generally completes in 10-12 hours to get the products $3 \mathrm{a}-3 \mathrm{e}$ (Scheme 2 ) in very good yield. The further refining of the products was done by column chromatography using ethylacetate: hexane as eluent. All the reactions were performed in vaccum fume hood by using carefully cleaned oven-dried lobachemie glassware. The stirring of the reaction mixtures was done on REMI made magnetic stirrers using teflon coated magnetic beads. Drying of diethyl ether was done over activated anhydrous calcium chloride followed by passing the thin sodium wire through it. Refluxing of acetonitrile was done over anhydrous $\mathrm{P}_{2} \mathrm{O}_{5}$ followed by distillation over anhydrous $\mathrm{K}_{2} \mathrm{CO}_{3}$. The dried acetonitrile was finally stored over the activated molecular sieves of size $4 \AA$ to prevent the infiltration of moisture. Reactions were monitored by TLC using silica gel GF254.
The chromatograms thus developed were viewed in ultraviolet light and staining was done with iodine. Column chromatography was done to purify the compounds. Silica gel of 100-200 mesh size was used using hexane and ethyl acetate as preferred eluents.

\section{${ }^{1} \mathrm{H}$ and ${ }^{13} \mathrm{C}$ NMR spectra and DEPT-135}

The spectra were recorded at a frequency $500 \mathrm{MHz}$ and $125 \mathrm{MHz}$ for ${ }^{1} \mathrm{H}$ and ${ }^{13} \mathrm{C}$ spectra respectively. $\mathrm{CDCl}_{3}$ and DMSO were used as preferred solvents with TMS as an internal standard. The ${ }^{1} \mathrm{H}$ NMR spectral data were reported in form of chemical shifts $(\delta \mathrm{ppm})$, multiplicity ( $\mathrm{s}=$ singlet, br $\mathrm{s}=$ broad singlet, $\mathrm{d}=$ doublet, $\mathrm{dd}=$ double doublet, $\mathrm{t}=$ triplet, $\mathrm{m}=$ multiplet) and the coupling constant (expressed as $J$ in Hertz). The ${ }^{13} \mathrm{C}$ and DEPT-135 NMR spectral data were represented in terms of chemical shift with +ve signals corresponding to $\mathrm{CH}_{3}$ and $\mathrm{CH}$ carbons and the -ve signals corresponding to $\mathrm{CH}_{2}$<smiles>C#CCn1c(C)c2ccccc2c1N[C@H](CC(C)C)C(C)C</smiles>

1) Azldo-acetlc acld /(EtOH:H2O - 9:1, CuSO4.5H2O $=0.02 \mathrm{mmol}$, Sodum ascorbate $-0.05 \mathrm{mmol}$ )

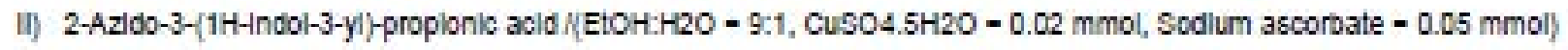

1ii) 2-Azido-3-(1H-ImidazOl-4-yl)-proplonic acld/(EtOH:H2O - 9:1, CuSO4.5H2O -0.02 mmol, Sodum ascorbate -0.05 mmol)

IV) 2-Azldo-4-carboxy-heptanedlolc acld/(EtOH:H2O - 9:1, CuSO4.5H2O - $0.02 \mathrm{mmol}$, Sodlum ascorbate $-0.05 \mathrm{mmo}$ )

V) 2-Azldo-4-(4-hydroxy-Denzy)-pentanedloic acld /(EtOH:H2O - 9:1, CuSO4.5H2O $-0.02 \mathrm{mmol}$, Sodlum ascorbate $-0.05 \mathrm{mmol}$ ) 
carbons while an absent signal points towards a quaternary carbon. SP 300 PYE UNI CAM Infrared Spectrophotometer was used to record the Infrared spectra with anhydrous $\mathrm{KBr}$ pellets.

\section{Mass spectra and LCMS procedure}

Bruker MicroTOF QII mass spectrometer (Bruker Daltonik, Bremen, Germany) machine calibrated with sodium formate (internal calibrant) was used to record the mass spectra. KdScientific automated pump with flow rate $180 \mu \mathrm{L} / \mathrm{h}$ was used to inject the sample to electrospray ionization source at a concentration $50 \mu \mathrm{M}$ in acetonitrilewater-formic acid (7:2.9:0.1). Dry $\mathrm{N}_{2}$ gas heated at $180^{\circ} \mathrm{C}$ was used for the desolvation of the injected solution. Optimisation of the various parameters of the mass spectrometer was done for obtaining a maximum ion abundance. Specifically, the capillary voltage was adjusted at $4500 \mathrm{~V}$ and the vacuum was sustained at $3-4 \times 10^{-7}$ mbar. For LC-MS, Dionex Ultimate 3000 system was coupled to the mass spectrometer. Chirobiotic ${ }^{\circ} 10 \mu \mathrm{m}$ chiral HPLC column $(25 \mathrm{~cm} \times 4.6$ $\mathrm{mm}$ ) was used for the analysis. A solution of Acetonitrile in water (1:1) was used as eluent. $2 \mu \mathrm{L}$ of sample (injection volume) was loaded to the column. The flow rate was maintained $0.2 \mathrm{ml}$ and the absorbance was set at 200, 220 and 254 nanometers. Sodium formate was used as internal calibrant.

\section{${ }^{1} \mathrm{H} /{ }^{13} \mathrm{C} / \mathrm{DEPT}-135$ NMR data of the test compounds}

[4-(3-Methyl-indol-1-ylmethyl)-[1,2,3] triazol-1-yl]-acetic acid (3a): The compound (2) was dissolved in 9:1 solution of EtOH: $\mathrm{H}_{2} \mathrm{O}$ and allowed to stir till a clear solution is obtained. To this clear solution was immediately added $0.02 \mathrm{mmol}$ of $\mathrm{CuSO}_{4} \cdot 5 \mathrm{H}_{2} \mathrm{O}$. After waiting for another 5 minutes, $0.05 \mathrm{mmol}$ sodium ascorbate was added to the reaction mixture and the contents were allowed to stir for 10 minutes. Finally, the azidoacetic acid (i) synthesized in Scheme 1, was added to the reaction mixture. The reaction was monitored by thin layer chromatography technique. The reaction generally completes in 8 hours to give a yellow colored powdery solid, $\mathrm{mp} 90-95^{\circ} \mathrm{C}, 80 \%$ yield, IR (KBr) vmax $3380(\mathrm{NH}), 1610(\mathrm{C}=\mathrm{O}) \mathrm{cm}^{-1} ;{ }^{1} \mathrm{H}$ NMR $\left(\mathrm{CDCl}_{3}, 500\right.$ $\mathrm{MHz}): \delta=9.42(\mathrm{~s}, 1 \mathrm{H}, \mathrm{COOH}) 2.307 .83-8.401(\mathrm{~m}, 3 \mathrm{H}, \mathrm{ArH}), 7.39-$ $7.43(\mathrm{~m}, 2 \mathrm{H}, \mathrm{ArH}), 4.20\left(\mathrm{~s}, 2 \mathrm{H}, \mathrm{CH}_{2}\right), 4.01\left(\mathrm{~s}, 2 \mathrm{H}, \mathrm{CH}_{2}\right), 2.25(\mathrm{~s}, 3 \mathrm{H}$, $\left.\mathrm{CH}_{3}\right),\left({ }^{13} \mathrm{C}\right.$ NMR normal/DEPT-135) (125 MHz, CDCl $): 181.27$ $(\mathrm{C}=\mathrm{O}), 138.66(\mathrm{C}), 134.24(\mathrm{C}), 128.11(\mathrm{CH}), 127.93(\mathrm{CH}), 125.74(\mathrm{C})$, 122.87( $\mathrm{ArCH}), 115.79(\mathrm{ArCH}), 113.30(\mathrm{ArCH}), 27.48$ (-ve, $\left.\mathrm{CH}_{2}\right), 21.98$ (-ve, $\left.\mathrm{CH}_{2}\right), 21.04\left(\mathrm{CH}_{3}\right)$; ESI-MS (HRMS) calculated for $\mathrm{C}_{14} \mathrm{H}_{14} \mathrm{~N}_{2} \mathrm{O}_{4}$ 271.1187. Found $\mathrm{m} / \mathrm{z} 271.1181\left([\mathrm{M}+\mathrm{H}]^{+}\right)$.

3-(1H-Indol-3-yl)-2-[4-(3-methyl-indol-1-ylmethyl)-[1,2,3] triazol-1-yl]-propionic acid (3b): The compound (2) was dissolved in 9:1 solution of EtOH: $\mathrm{H}_{2} \mathrm{O}$ and allowed to stir till a clear solution is obtained. To this clear solution was immediately added $0.02 \mathrm{mmol}$ of $\mathrm{CuSO}_{4} \cdot 5 \mathrm{H}_{2} \mathrm{O}$. After waiting for another 5 minutes, $0.05 \mathrm{mmol}$ sodium ascorbate was added to the reaction mixture and the contents were allowed to stir for 10 minutes. Lastly, the 2-Azido-3-(1H-indol-3-yl)propionic acid (ii) obtained in Scheme 2, was added to the reaction mixture. The reaction was monitored by thin layer chromatography technique. The reaction generally completes in 8 hours to give a bright yellow coloured solid, $\mathrm{mp} 137-142^{\circ} \mathrm{C}, 69 \%$ yield, $[\alpha] \mathrm{D}^{25}=+124$ (c 0.01 , $\mathrm{MeOH}), \mathrm{IR}(\mathrm{KBr}) v \max 3390(\mathrm{NH}), 3191(\mathrm{NH}), 1632(\mathrm{C}=\mathrm{O}) \mathrm{cm}^{-1} ;{ }^{1} \mathrm{H}$ NMR (500 MHz, DMSO d6): $\delta=8.16(\mathrm{~s}, 1 \mathrm{H}, \mathrm{COOH}), 6.70-7.50(\mathrm{~m}$, $9 \mathrm{H}, \mathrm{ArH}), 6.70(\mathrm{~s}, 1 \mathrm{H}, \mathrm{ArH}), 4.51(\mathrm{t}, \mathrm{J}=10 \mathrm{~Hz}, 1 \mathrm{H}, \mathrm{ArH}, 1 \mathrm{H}, \mathrm{CH}), 4.20$ $\left(\mathrm{s}, 2 \mathrm{H}, \mathrm{CH}_{2}\right), 3.45-3.63\left(\mathrm{~m}, 2 \mathrm{H}, \mathrm{CH}_{2}\right), 2.26\left(\mathrm{~s}, 3 \mathrm{H}, \mathrm{CH}_{3}\right) ;\left({ }^{13} \mathrm{C} \mathrm{NMR}\right.$ normal/DEPT- 135) (125 MHz, DMSO d6): $179.98(\mathrm{C}=\mathrm{O}), 136.70(\mathrm{C})$, $134.40(\mathrm{C}), 130.92(\mathrm{ArCH}), 127.47(\mathrm{ArCH}), 125.41(\mathrm{ArCH}), 123.83$ $(\mathrm{ArCH}), 121.60(\mathrm{ArCH}), 119.44(\mathrm{ArCH}), 118.00(\mathrm{ArCH}), 114.60$
$(\mathrm{ArCH}), 111.98(\mathrm{ArCH}), 109.85(\mathrm{C}), 107.07(\mathrm{C}), 53.15(\mathrm{CH}), 26.61$ $\left(\mathrm{CH}_{2}\right), 25.45\left(\mathrm{CH}_{2}\right), 21.58\left(\mathrm{CH}_{3}\right)$; ESI-MS (HRMS) calculated for $\mathrm{C}_{23} \mathrm{H}_{21} \mathrm{~N}_{5} \mathrm{O}_{2} 400.1775$. Found $\mathrm{m} / \mathrm{z} 400.1700[\mathrm{M}+\mathrm{H}]^{+}$.

2-[4-(3-Methyl-indol-1-ylmethyl)-[1,2,3] triazol-1-yl]-3(1H-[1,2,3] triazol-4-yl)- propionic acid (3c): The compound (2) was dissolved in 9:1 solution of EtOH: $\mathrm{H}_{2} \mathrm{O}$ and allowed to stir till a clear solution is obtained. To this clear solution was immediately added $0.02 \mathrm{mmol}$ of $\mathrm{CuSO}_{4} .5 \mathrm{H}_{2} \mathrm{O}$. After waiting for another 5 minutes, 0.05 mmol sodium ascorbate was added to the reaction mixture and the contents were allowed to stir for 10 minutes. Finally, the 2-Azido-3(1H-imidazol-4-yl)-propionic acid (iii) procured in Scheme 2, was added to the reaction mixture. The reaction was monitored by thin layer chromatography technique. The reaction generally completes in 8 hours to get a grey coloured solid, $\mathrm{mp} 121-126^{\circ} \mathrm{C}, 65 \%$ yield, $[\alpha] \mathrm{D}^{25}=$ +154 (c 0.01, MeOH), IR (KBr) vmax $3299(\mathrm{NH}), 1600(\mathrm{C}=\mathrm{O}) \mathrm{cm}^{-1} ;{ }^{1} \mathrm{H}$ NMR $\left(\mathrm{CDCl}_{3}, 500 \mathrm{MHz}\right): \delta=9.21(\mathrm{~s}, 1 \mathrm{H}, \mathrm{COOH}), 7.45-7.89(\mathrm{~m}, 2 \mathrm{H}$, ArH), 6.83-7.39 (m, 5H, ArH), $6.82(\mathrm{~s}, 1 \mathrm{H}, \mathrm{ArH}), 4.41(\mathrm{t}, \mathrm{J}=15 \mathrm{~Hz}, 1 \mathrm{H}$, $\mathrm{CH}), 4.20\left(\mathrm{~s}, 2 \mathrm{H}, \mathrm{CH}_{2}\right), 3.33$ (d, J= $\left.10 \mathrm{~Hz}, 2 \mathrm{H}, \mathrm{CH}_{2}\right), 2.27\left(\mathrm{~s}, 3 \mathrm{H}, \mathrm{CH}_{3}\right)$; $\left({ }^{13} \mathrm{CNMR}\right.$ normal/DEPT- 135) (125 MHz, DMSO d6): $(\mathrm{C})=171.97$ $(\mathrm{COOH}), 148.95(\mathrm{ArCH}), 138.64(\mathrm{ArCH}), 136.73(\mathrm{ArCH}), 127.49(\mathrm{C})$, $125.96(\mathrm{C}), 121.59(\mathrm{ArCH}), 119.05(\mathrm{ArCH}), 116.64(\mathrm{ArCH}), 111.04$ $(\mathrm{ArCH}), 107.08(\mathrm{C}), 54.27(\mathrm{CH}), 28.61\left(\mathrm{CH}_{2}\right), 25.46\left(\mathrm{CH}_{2}\right), 21.24$ $\left(\mathrm{CH}_{3}\right)$; ESI-MS (HRMS) calculated for $\mathrm{C}_{17} \mathrm{H}_{17} \mathrm{~N}_{7} \mathrm{O}_{2} 352.1524$ Found $\mathrm{m} / \mathrm{z} 352.1523[\mathrm{M}+\mathrm{H}]^{+}$.

2-[4-(3-Methyl-indol-1-ylmethyl)- [1,2,3] triazol-1-yl] pentanedioic acid (3d): The compound (2) was dissolved in 9:1 solution of EtOH: $\mathrm{H}_{2} \mathrm{O}$ and allowed to stir till a clear solution is obtained. To this clear solution was immediately added $0.02 \mathrm{mmol}$ of $\mathrm{CuSO}_{4} .5 \mathrm{H}_{2} \mathrm{O}$. After waiting for another 5 minutes, $0.05 \mathrm{mmol}$ sodium ascorbate was added to the reaction mixture and the contents were allowed to stir for 10 minutes. Finally, the 2-Azido-4-carboxy-heptanedioic acid (iv) obtained in Scheme 2, was added to the reaction mixture. The reaction was monitored by thin layer chromatography technique. The reaction generally completes in 8 hours to give a dark brown solid, $\mathrm{mp} 111$ $116^{\circ} \mathrm{C}, 85 \%$ yield, $[\alpha] \mathrm{D}^{25}=+23(\mathrm{c} 0.01, \mathrm{MeOH})$; IR $(\mathrm{KBr})$ vmax 3412 $\mathrm{NH}), 1574(\mathrm{C}=\mathrm{O}) \mathrm{cm}^{-1} ;{ }^{1} \mathrm{H}$ NMR (DMSO d6, $\left.500 \mathrm{MHz}\right): \delta=10.41(\mathrm{~s}$, $1 \mathrm{H}, \mathrm{COOH}), 9.81(\mathrm{~s}, 1 \mathrm{H}, \mathrm{COOH}), 7.91(\mathrm{~s}, 1 \mathrm{H}, \mathrm{ArH}), 7.53-7.82(\mathrm{~m}, 2 \mathrm{H}$, $\operatorname{ArH}), 7.22-7.39(\mathrm{~m}, 3 \mathrm{H}, \mathrm{ArH}), 4.39(\mathrm{t}, \mathrm{J}=5 \mathrm{~Hz}, 1 \mathrm{H}, \mathrm{CH}), 4.20(\mathrm{~s}, 2 \mathrm{H}$, $\left.\mathrm{CH}_{2}\right), 2.36-2.72(\mathrm{~m}, 2 \mathrm{H} \mathrm{x} \mathrm{CH}), 2.27\left(\mathrm{~s}, 3 \mathrm{H}, \mathrm{CH}_{3}\right) ;\left({ }^{13} \mathrm{C} \mathrm{NMR} \mathrm{normal} /\right.$ DEPT- 135) (125 MHz, DMSO d6): $(\mathrm{C})=180.03(\mathrm{COOH}), 179.55$ $(\mathrm{COOH}), 145.55(\mathrm{ArCH}), 134.66(\mathrm{ArCH}), 130.93(\mathrm{C}), 127.14(\mathrm{C})$, $123.86(\mathrm{C}), 122.03(\mathrm{ArCH}), 116.85(\mathrm{C}), 114.55(\mathrm{ArCH}), 113.53(\mathrm{ArCH})$, $109.82(\mathrm{C}), 53.78(\mathrm{CH}), 29.57\left(\mathrm{CH}_{2},-\mathrm{ve}\right), 25.78\left(\mathrm{CH}_{2},-\mathrm{ve}\right), 25.06\left(\mathrm{CH}_{2}\right.$, -ve), $21.53\left(\mathrm{CH}_{3}\right)$; ESI-MS (HRMS) calculated for $\mathrm{C}_{17} \mathrm{H}_{18} \mathrm{~N}_{4} \mathrm{O}_{4} 342.1408$ Found $\mathrm{m} / \mathrm{z} 342.1410[\mathrm{M}+\mathrm{H}]^{+}$.

3-(4-Hydroxy-phenyl)-2-[4-(3-methyl-indol-1-ylmethyl)-[1,2,3] triazol-1-yl]-propionic acid (3e): The compound (2) was dissolved in 9:1 solution of EtOH: $\mathrm{H}_{2} \mathrm{O}$ and allowed to stir till a clear solution is obtained. To this clear solution was immediately added $0.02 \mathrm{mmol}$ of $\mathrm{CuSO}_{4} .5 \mathrm{H}_{2} \mathrm{O}$. After waiting for another 5 minutes, $0.05 \mathrm{mmol}$ sodium ascorbate was added to the reaction mixture and the contents were allowed to stir for 10 minutes. Finally, the 2-Azido-4-(4-hydroxybenzyl)-pentanedioic acid (v) was added to the reaction mixture. The reaction was monitored by thin layer chromatography technique. The reaction generally completes in 8 hours to get a brown solid, mp 145 $153^{\circ} \mathrm{C}, 78 \%$ yield, $[\alpha] \mathrm{D}^{25}=+35(\mathrm{c} 0.01, \mathrm{MeOH})$; IR $(\mathrm{KBr}) \nu \max 3315$ $(\mathrm{NH}), 1701(\mathrm{C}=\mathrm{O}) \mathrm{cm}^{-1} ;{ }^{1} \mathrm{H}$ NMR $\left(\mathrm{CDCl}_{3}, 500 \mathrm{MHz}\right): \delta=9.15(\mathrm{~s}, 1 \mathrm{H}$, $\mathrm{COOH})$, 7.73-7.94 (m, 2H, ArH), 7.53-7.63 (m, 1H, ArH), 6.87-7.52 $(\mathrm{m}, 3 \mathrm{H}, \mathrm{ArH}), 4.42(\mathrm{t}, \mathrm{J}=15 \mathrm{~Hz}, 1 \mathrm{H}, \mathrm{CH}), 4.35\left(\mathrm{~s}, 2 \mathrm{H}, \mathrm{CH}_{2}\right), 3.33(\mathrm{~d}, \mathrm{~J}=$ 
$\left.3 \mathrm{~Hz}, 2 \mathrm{H}, \mathrm{CH}_{2}\right), 2.20$ (s, 3H, $\left.\mathrm{CH}_{3}\right) ;\left({ }^{13} \mathrm{C} \mathrm{NMR}\right.$ normal/DEPT- 135) $(125$ $\left.\mathrm{MHz}, \mathrm{CDCl}_{3}\right):(\mathrm{C})=173.53(\mathrm{COOH}), 145.30(\mathrm{C}), 144.82(\mathrm{C}), 135.27$ $(\mathrm{ArCH}), 134.94(\mathrm{ArCH}), 130.75(\mathrm{C}), 129.87(\mathrm{ArCH}), 126.81(\mathrm{ArCH})$, 126.33 (ArCH), $124.55(\mathrm{ArCH}), 123.30(\mathrm{ArCH}), 121.36(\mathrm{ArCH}), 113.30$ $(\mathrm{ArCH}), 109.04(\mathrm{C}), 107.24(\mathrm{C}), 58.75(\mathrm{CH}), 29.29\left(\mathrm{CH}_{2},-\mathrm{ve}\right), 25.19$ $\left(\mathrm{CH}_{2},-\mathrm{ve}\right), 21.53\left(\mathrm{CH}_{3}\right)$; ESI-MS (HRMS) calculated for $\mathrm{C}_{21} \mathrm{H}_{20} \mathrm{~N}_{4} \mathrm{O}_{3}$ 377.1615 Found $\mathrm{m} / \mathrm{z} 377.1615[\mathrm{M}+\mathrm{H}]^{+}$.

\section{Results and Discussion}

\section{MIC80}

The antifungal activity of the test compounds $\mathbf{3}(\mathbf{a}-\mathbf{e})$ was evaluated by performing the MIC80 assay. Ten successive dilutions of the test compounds were prepared alongwith the solvent control with yeast extract peptone dextrose (YEPD) medium in a 96-well plate. The overnight grown cells of the BWP 17 strain of the fungus Candida Albicans were resuspended in a $0.9 \%$ saline solution to give a resultant optical density of 0.1 at a wavelength of $570 \mathrm{~nm}$ (OD570) These cells were further diluted 100 times in SDM medium. $100 \mu$ of these diluted cells were added to each of the wells in the 96 well plate except the column 11 which was taken as media control to examine any kind of contamination while performing the assay. Column 12 which was taken as positive control contained the fungal cells only in the growth medium. The assay was performed in duplicates. After preparing the plate it was incubated at a temperature of $30^{\circ} \mathrm{C}$ for a duration of 48 hours. Afterwards, the monitoring of OD570 of the cells was done using a micro plate reader. The percent inhibition of the fungal growth in the presence of test compounds $\mathbf{3}$ (a-e) was determined with respect to the positive control by deducting the percent inhibition due to the solvent control. The MIC80 values were thus calculated by plotting a graph between percent inhibition versus concentration of the test compound using the Graphpad Prism software. The percent inhibition of the fungi was determined at eight different concentrations of the test compounds $\mathbf{3}$ (a-e). The Compounds $\mathbf{3 b}, \mathbf{3} \mathbf{c}$, and $\mathbf{3 d}$ containing tryptophan, histidine and glutamic acid substituents appended to the indole through a triazole linker were found to be most effective against CABWP-17 with MIC80 of 50.2, 78.81, and $188.05 \mu \mathrm{g} / \mathrm{ml}$, respectively. Compounds $\mathbf{3 a}$ and $\mathbf{3 e}$ with glycine and tyrosine substituents appended to indole via azole linker were found to be least effective with MIC80 values in the range of $617.90-752.78 \mu \mathrm{g} / \mathrm{ml}$.

\section{Disc diffusion assay}

The disc diffusion assay was performed to furthur explore the antifungal efficacy of the test compounds. Taking YEPD as the culture medium the cells of the BWP17 strain of candida albicans were grown overnight at $30^{\circ} \mathrm{C}$. A $90 \mathrm{~mm}$ diameter YEPD-agar plate was then prepared and $10^{7}$ cells were spread on it. This plate was then dried for around 10-15 minutes. Small filter paper discs (5 mm diameter) were prepared, sterilized and placed on this plate with the help of clean forceps. A known concentration of each test compound dissolved in an appropriate solvent was spotted on the paper disc. Similar procedure was repeated with the solvent controls. After incubating the assay plates for 48 hours at $30^{\circ} \mathrm{C}$ the growth of the fungal cells at the periphery of the disc was checked. The diameter of the circle around the disc with no fungal growth corresponds to inhibition zone. In order to maintain an effective concentration of the test compounds in the culture medium the disc diffusion assay was performed at a slightly superior concentration than the MIC80 values. The images of inhibition zone $(\mathrm{mm})$ of fungal culture in the presence of test compounds compared with the corresponding solvent are shown in Tables 1 and 2. The zone of inhibition was highest for the Compound $\mathbf{3 b}$ followed by the compound $3 \mathrm{c}$ at concentrations $100 \mu \mathrm{g} / \mathrm{ml}$ and $50 \mu \mathrm{g} / \mathrm{ml}$. Whereas, the zone of inhibition was much narrower in case of the compounds $\mathbf{3 a}$, 3d and $3 e$.

\section{Spot assay}

The results of MIC80 evaluation and the disc diffusion assay led us to select the compounds $\mathbf{3 b}$ and $\mathbf{3} \mathbf{c}$ for performing the spot assay. A known concentration of the compounds $3 \mathbf{b}$ and $\mathbf{3 c}$ was added to the medium containing YEPD and agar. Solvent control plates were also prepared. The plates with naked YEPD-agar medium served as positive controls. The fungal cells growing overnight on the YEPD medium at a temperature of $30^{\circ} \mathrm{C}$ served as primary culture medium. The secondary culture was prepared from a $4 \%$ inoculum of the primary culture medium. From the secondary culture were prepared five serial dilutions of cell suspension with $0.9 \%$ saline solution to give a resultant OD of $0.2,0.04,0.008,0.00016$ and 0.00032 at $570 \mathrm{~nm}$. A $5 \mu \mathrm{l}$ volume from each cell suspension was added to all the plates. After incubating the plates at $30^{\circ} \mathrm{C}$ their images were recorded after 24 hours and 36 hours respectively. The spot assay indicates an impaired fungal growth in the presence of the compounds $\mathbf{3 b}$ and $\mathbf{3 c}$. The results were quite comparable with the commercially used drug ketoconazole which showed a similar growth inhibition pattern after 24 hours and 36 hours of treatment (Figure 1).

\section{SEM analysis}

The morphological changes occurring in the fungal cells in the presence of test compounds was monitored through the Scanning Electron Microscopy. The CA BWP17 cells were grown in the presence of the most active compound $\mathbf{3 b}$. The cells were pelleted, washed and then fixed into $2.5 \%$ glutaraldehyde and $2 \%$ Paraformaldehyde in $0.1 \mathrm{M}$ phosphate buffer at $4^{\circ} \mathrm{C}$. In order to get a superior staining of the intracellular membranes, the secondary fixing of the cells was done in

\begin{tabular}{|c|c|c|}
\hline Compound & MIC $_{\mathbf{8 0}}(\boldsymbol{\mu g} / \mathbf{m l})$ & ClogP (Experimental) \\
\hline 3a & 617.9 & 3.45 \\
\hline 3b & 50.2 & 1.89 \\
\hline 3c & 78.81 & 1.78 \\
\hline 3d & 188.05 & -1.01 \\
\hline 3e & 752.78 & 1.99 \\
\hline
\end{tabular}

Table 1: MIC80 values and experimentally determined hydrophilicity index of compounds 3a-e for CA BWP17 strain.

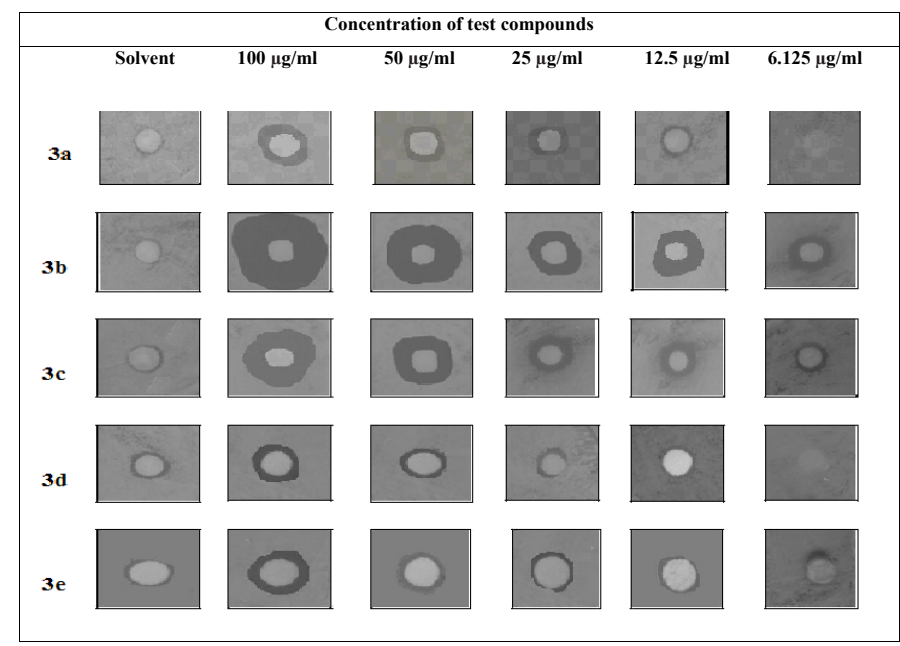

Table 2: Diameter (in $\mathrm{mm}$ ) of the zone of inhibition in the disc diffusion assay of highly effective compounds against CA BWP17. 


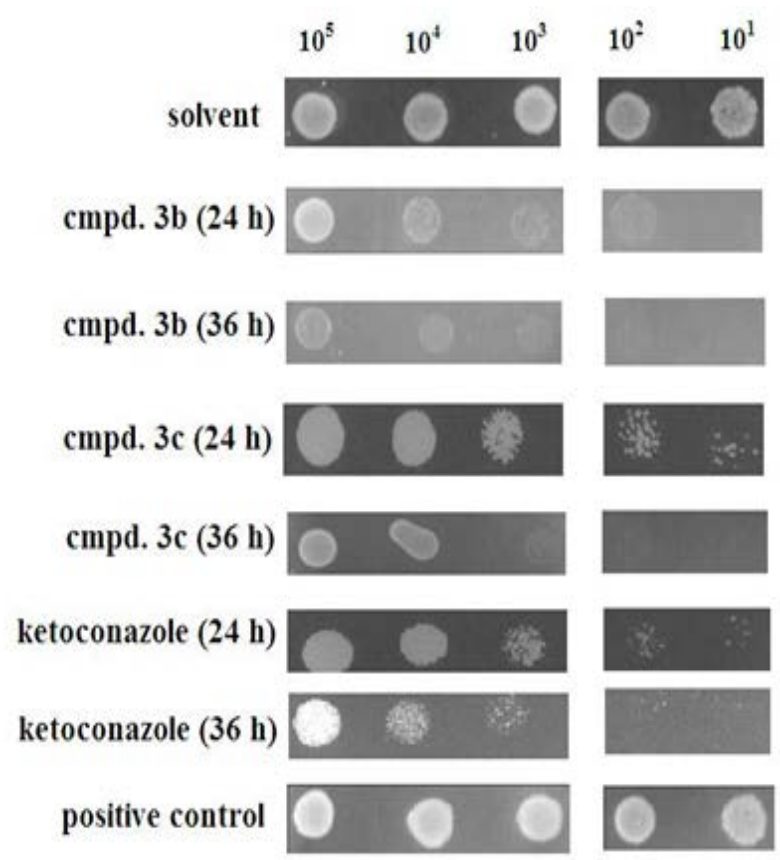

Figure 1: Spot assay for CA BWP17 in the presence of active compounds $\mathbf{3 b}$ and $3 c$.

Osmium tetraoxide $\left(\mathrm{OsO}_{4}\right)$. The dehydration of the sample was done by sequentially treating the cells with increased concentrations of acetone from $50 \%$ to $95 \%$. After drying the sample with critical point drier it was mounted on the stub SCM. Spatter coater was used for the gold coating of cells. The cells were viewed under the Carl Zeiss Microscope EVO 40 at $30 \mathrm{KV}$. The morphological changes were noticeable on the fungal membrane in the presence of compound $\mathbf{3 b}$ which got augmented with the passage of time. The SEM investigations clearly indicate that the compound $\mathbf{3 b}$ targets the fungal membrane (Figure 2).

\section{GC analysis}

To explore the inhibition of the enzyme lanosterol 14- $a$ demethylase in the presence of the test compounds, the levels of ergosterol and lanosterol in the BWP17 cells treated with the compound 3b were assessed using GC-MS. The cells treated with compound $3 \mathrm{~b}$ showed a depleted ergosterol content compared with the untreated cells. The levels of lanosterol on the other hand were found to increase. This clearly indicates an impaired functioning of the lanosterol 14- $\alpha$ demethylase enzyme in the presence of the compound $3 \mathrm{~b}$ due to which much of the subsrate lanosterol is not metabolized to ergosterol and hence it starts building up in the cells treated with the test compound (Figure 3). The level of lanosterol in the same cells was found to increase. The bars represent averages of three independent assays and the standard deviations are represented by error bars.

\section{Docking analysis}

The inhibition of the enzyme activity by the test compounds was justified by docking experiments wherein the test compounds were docked in the active site of the enzyme lanosterol 14- $\alpha$ demethylase by using ArgusLab.exe software. Both the stereoisomers of the test compounds were docked and it was found that the ' $R$ ' stereoisomer showed a better docking profile in the enzyme active site. This was in accordance with the experimental data where the D-amino acids were selected for synthesizing the compounds. The numerous hydrogen bonding interactions were observed for the compounds $\mathbf{3 b}$ and $\mathbf{3 c}$ which interact with the active site residues principally through $\mathrm{N}$ atom of the triazole ring. The ' $R$ ' stereoisomer of compound $3 \mathrm{~b}$ interacts with the residues Y576, Y590 and F597 via $\mathrm{COOH}$ and $\mathrm{N}$ atom of the nitrogen heterocycle by hydrogen bonding interactions of length 1.23 $\AA, 1.22 \AA, 1.77 \AA$ and $1.69 \AA$ respectively. Similarly, the R' stereoisomer of the compound $3 c$ interacts with the residues Y576, F597, G752 and A756 via $\mathrm{N}$ atom of the triazole ring and $\mathrm{COOH}$ functional group with hydrogen bonding interactions of length $2.22 \AA, 1.88 \AA$, $1.72 \AA$ and 1.61 Å respectively (Table 3; Figures 4 and 5).

\section{Study of influx - efflux of R6G in CA BWP17 in presence of compounds}

Several of the commercially available antifungal drugs are subjected to the cellular efflux pumps. To check the vulnerability of the test compounds $\mathbf{3 b}$ and $\mathbf{3} \mathbf{c}$ towards the fungal efflux pumps, the R6G effluxinflux assay was performed. R6G is a substrate of fungal efflux pumps. It was envisioned that if there is a competition between test compounds and R6G to interact with efflux pump, the transportation of R6G out of the cell will be debarred. Conversely, if there is efflux of R6G in presence of compounds it would indicate that there is no interaction between compound and efflux pump protein. Influx-efflux of R6G in fungal cells was monitored by recording the absorbance and fluorescence of extracellular fluid. CA BWP17 primary/secondary culture was grown as described earlier. After centrifugation the cells were taken in PBS solution or non-growing medium. The PBS solution was now divided into three portions. One part was taken positive control, second part was considered as solvent control and the third part was treated with the test compounds. R6G was added to all the three portions. The assay was performed in triplicates. An increase in R6G influx was observed in positive control and solvent control experiments while in presence of compound $\mathbf{3 b}$, most of R6G entered the cell immediately and no change in R6G influx was observed with time. Similarly, the initial efflux of R6G in the presence of compound $\mathbf{3 b}$ was found to be much faster compared to positive control and solvent control. Both influx as well as efflux assays were pointing towards rupture of the fungal membrane in presence of compound $\mathbf{3 b}$ making free passage for influx and efflux of R6G (Figures 6-8). Similar trends were observed during the efflux of R6G in presence of compound 3c (Figures 9-29).

\section{Conclusions}

As conclusion, the amino acid tethered triazoles were identified with momentous antifungal activities. The minimum inhibitory concentration assay revealed that the compounds $\mathbf{3 b}$ and $\mathbf{3} \mathbf{c}$ with tryptophan and histidine substituents were most active inhibitors of the BWP 17 strain of fungi candida albicans. The observation was further confirmed by performing the spot assay and disc diffusion assays. The GC analysis of the metabolites of the fungal membrane revealed an elevated concentration of the ergosterol which led us to conclude that the test compounds actively target the enzyme lanosterol 14- $\alpha$ demethylase. The docking of the test compounds in the active site of the enzyme further strengthened this observation. The study of the R6G efflux/influx pumps in the fungal membrane revealed that the test compounds adversely influence the membrane integrity leading to the creation of a free passage for the entry and exit of metabolites across the membrane. Overall, highly efficient antifungal leads with membrane lysing properties were recognized.

\section{Acknowledgements}

PP thanks the University of Petroleum and Energy Study for providing the requisite resources for the synthesis of compounds. The state of the art instrumental 
Citation: Prasher P (2016) Identification of Amino Acid Tethered Triazoles as Potential Antifungal Leads: Appraisal of their Mode of Action. Chem Sci J 7: 139. doi: 10.4172/2150-3494.1000139
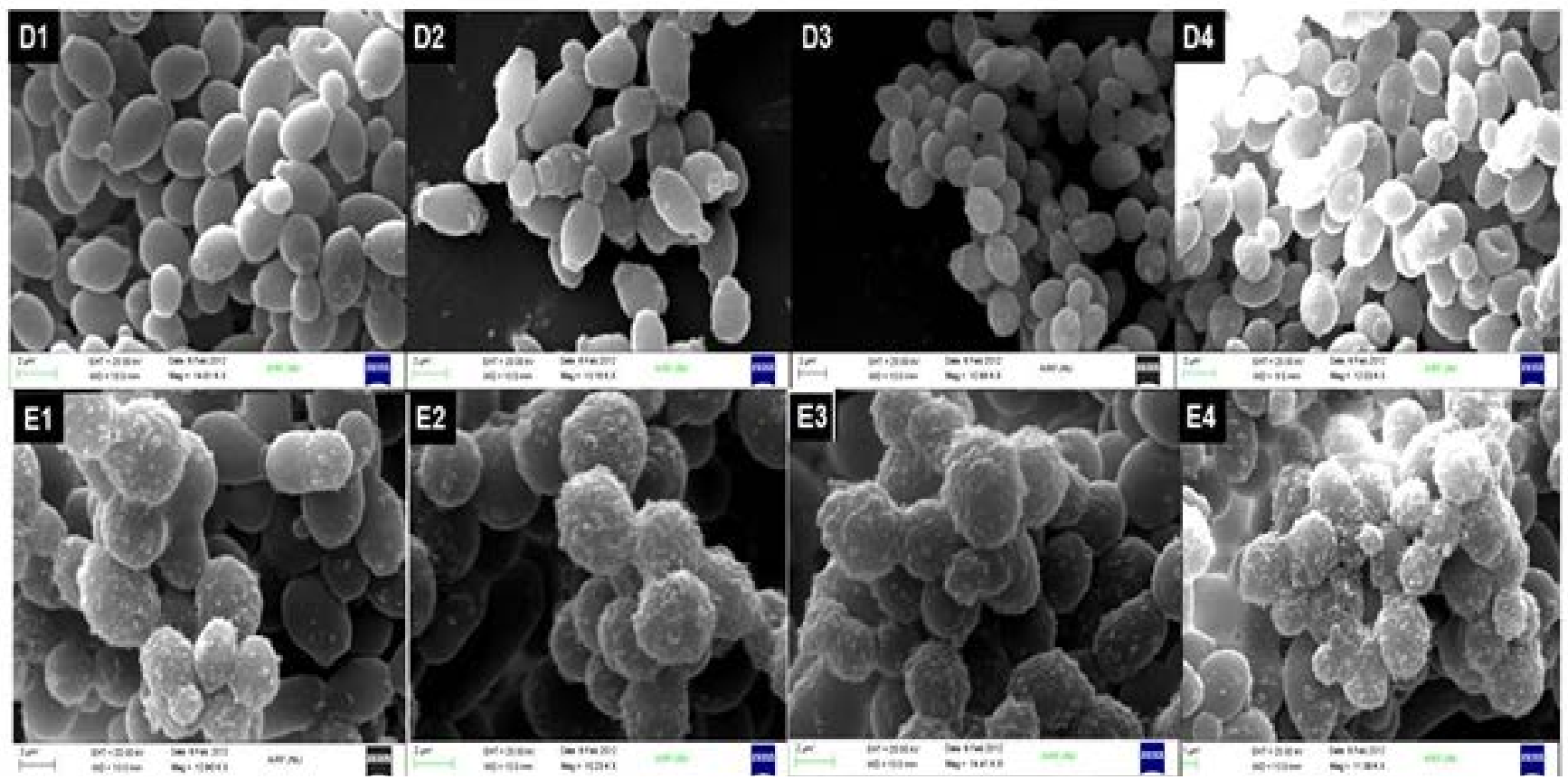

Figure 2: SEM images of CA BWP17 culture grown in the presence and absence of compound $3 \mathbf{b}$ at different time intervals. D1, D2, D3 and D4 indicate the growth of cells under the optimum conditions in the absence of the compound after $2 \mathrm{~h}, 6 \mathrm{~h}, 10 \mathrm{~h}$ and $16 \mathrm{~h}$ respectively. E1, E2, E3 and E4 indicate the growth of the cells in the presence of compound $3 \mathrm{~b}$ after $2 \mathrm{~h}, 6 \mathrm{~h}, 10 \mathrm{~h}$ and $16 \mathrm{~h}$ respectively.

\begin{tabular}{|c|c|c|c|c|c|}
\hline \multirow{2}{*}{$\begin{array}{c}\text { Compd. } \\
\qquad \mathbf{3 a}\end{array}$} & \multirow{2}{*}{$\begin{array}{c}\begin{array}{c}\text { Docking Score } \\
\text { (Kcal/mol) }\end{array} \\
-10.45 \\
\end{array}$} & \multicolumn{4}{|c|}{ Hydrogen bond interactions } \\
\hline & & Y576 (2.44 Å), COOH & - & - & - \\
\hline 3b (R) & -20.21 & Y576 (1.23 Å), COOH & Y576 (1.22A), N (azole) & 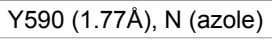 & 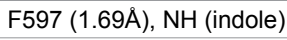 \\
\hline $3 b(S)$ & -12.34 & $\mathrm{G} 752(3.11 \AA), \mathrm{COOH}$ & $\mathrm{H} 372(2.61 \AA), \mathrm{COOH}$ & 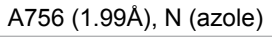 & \\
\hline $3 c(R)$ & -18.7 & Y576 (2.22 Å), N (azole) & F597 (1.88 Å), N (imidazole) & G752 (1.72Å), N (azole) & 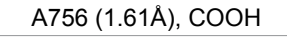 \\
\hline $3 c(S)$ & -10.78 & $\mathrm{G} 752(3.61 \AA), \mathrm{COOH}$ & Q557 (2.91^), COOH & - & - \\
\hline 3d (R) & -15.41 & Y576 (2.45 Å), COOH & $\mathrm{A} 756(2.22 \AA), \mathrm{COOH}$ & 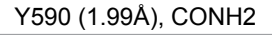 & - \\
\hline 3d (S) & -8.98 & F597 (2.99 Å), COOH & Y576 (3.59A), COOH & - & - \\
\hline $3 e(R)$ & -14.01 & A756 (2.10 A), CONH2 & F597 (2.36 A ), COOH & 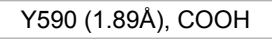 & - \\
\hline $3 e(S)$ & -8.29 & F597 (3.14 Å), COOH & - & - & - \\
\hline Ketoconazole & -16.81 & Y576 (1.45 Å), N (imidazole) & F597 (1.66 Å), N (imidazole) & - & - \\
\hline
\end{tabular}

Table 3: The docking characteristics of the different stereoisomers of the compounds in the active site of the enzyme lanosterol 14- $\alpha$ demethylase.

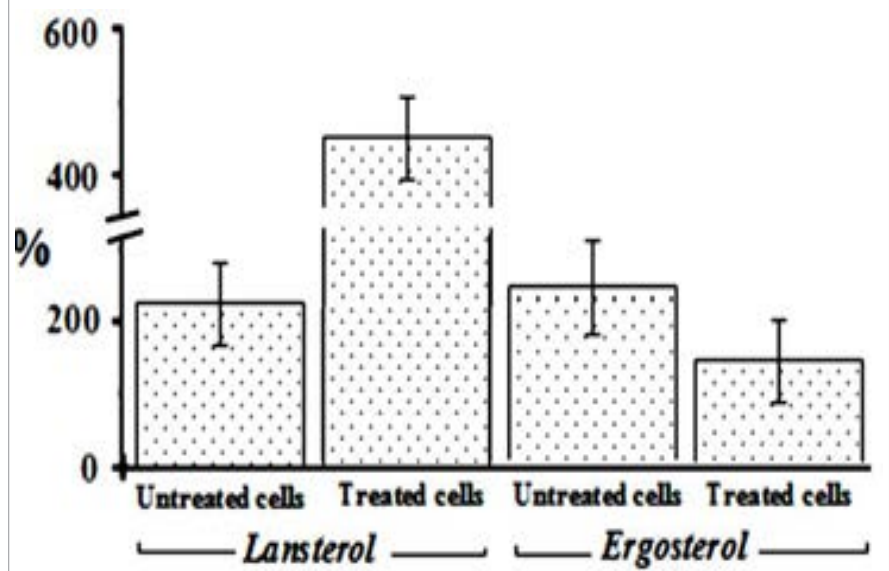

Figure 3: The figure indicates a depleted levels of ergosterol in the cells treated with compound $3 \mathrm{~b}$.

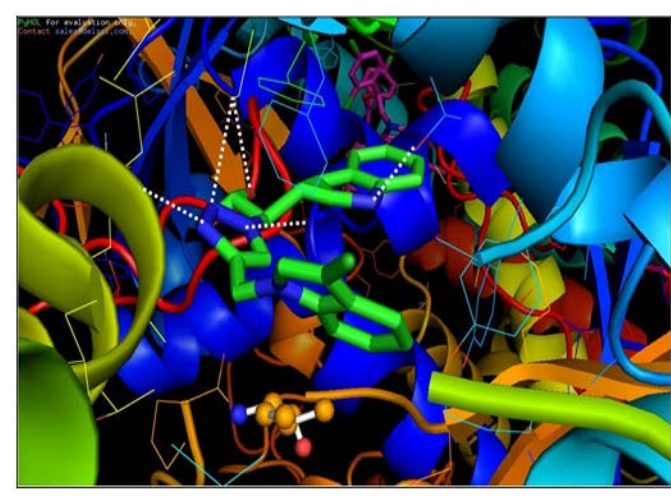

Figure 4: The crystal coordinates of the enzyme lanosterol 14- $\alpha$ demethylase (pdb ID 3jus) in association with the compound $3 \mathrm{~b}$. The white dotted lines represent the $\mathrm{H}$-bonding interactions between compound and the amino acid residues in the active site of the enzyme. The interaction are principally through the triazole nucleus and $\mathrm{COOH}$ functional group of the compound. 


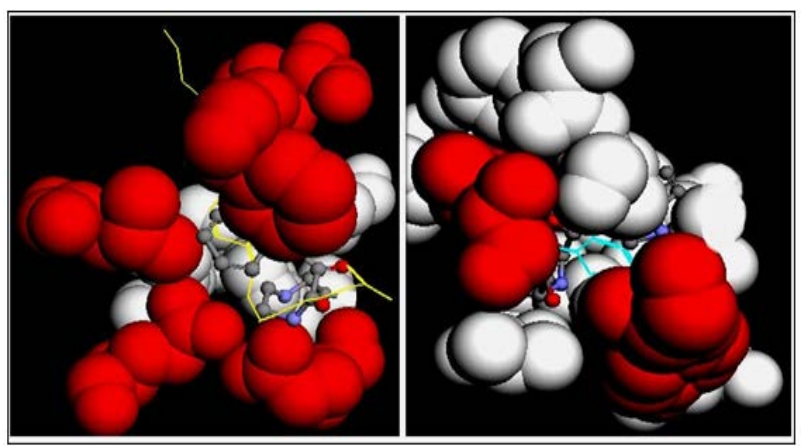

Figure 5: CPK model for showing the placement of the compound $3 \mathrm{~b}$ in the active site of the enzyme lanosterol 14- $a$ demethylase in the presence of the natural inhibitor (shown in yellow and blue wireframe)

\begin{tabular}{|l|l|l|l|l|}
\hline Compound & $\begin{array}{l}\text { Energy minimized } \\
\text { structure }\end{array}$ & Nviolations & Volume & ClogP \\
\hline $3 \mathrm{a}$ & & & & \\
\hline $3 \mathrm{~b}$ & & & & \\
\hline $3 \mathrm{c}$ & & & & \\
\hline $3 \mathrm{~d}$ & & & & \\
\hline
\end{tabular}

Figure 6: Lipinski Parameters for the compounds. ClogP - hydrophilicity index, Nviolations - number of violations from Lipinski parameters.

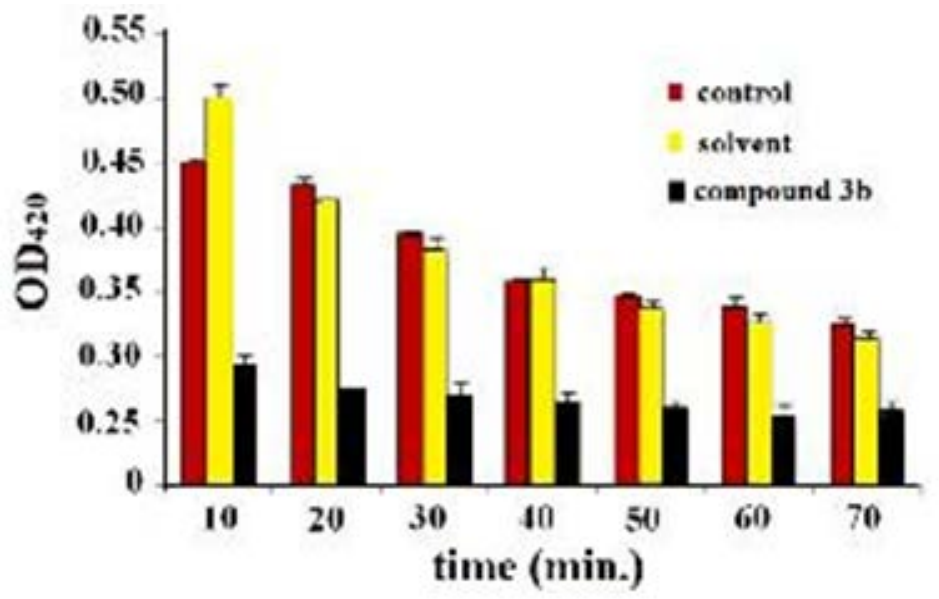

Figure 7: R6G influx in the presence of compound $\mathbf{3 b}$ 
(a)

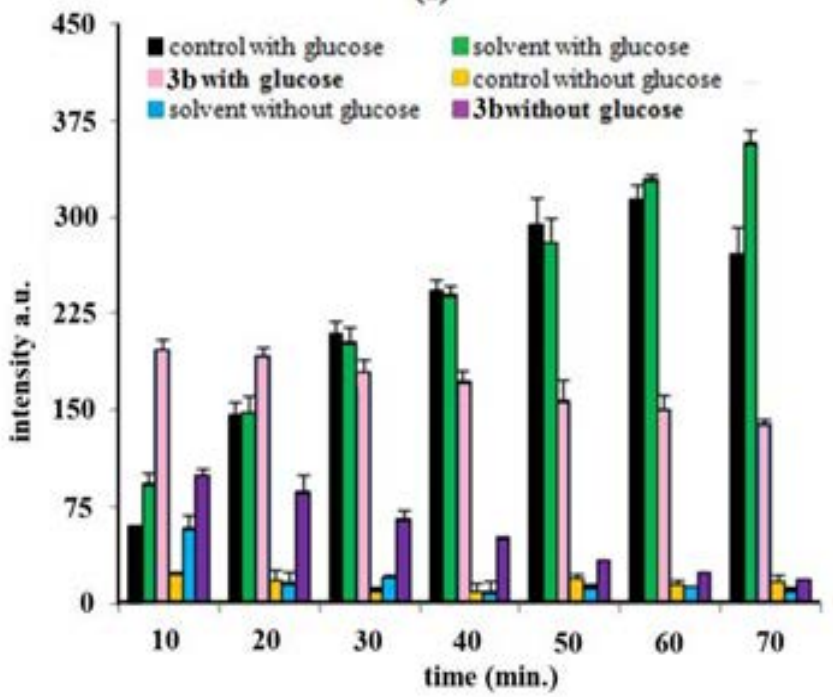

(b)

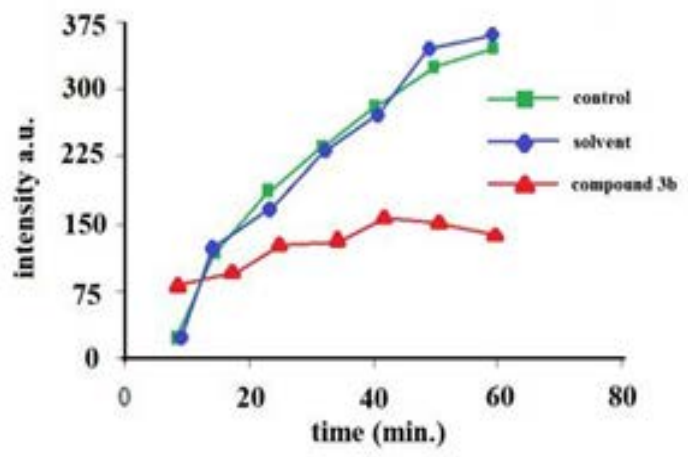

Figure 8: (a) R6G efflux in the presence of compound 3b. (b) Differentiation between active and passive efflux.

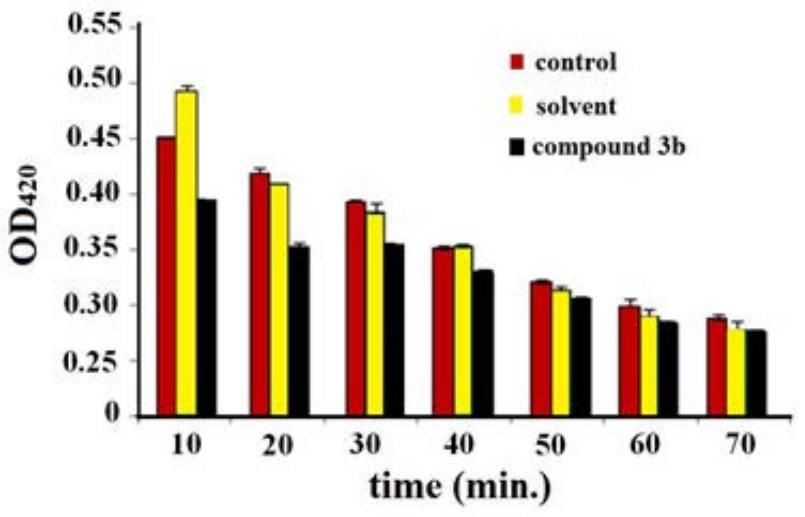

Figure 9: Influx of R6G in the presence of compound 3c.

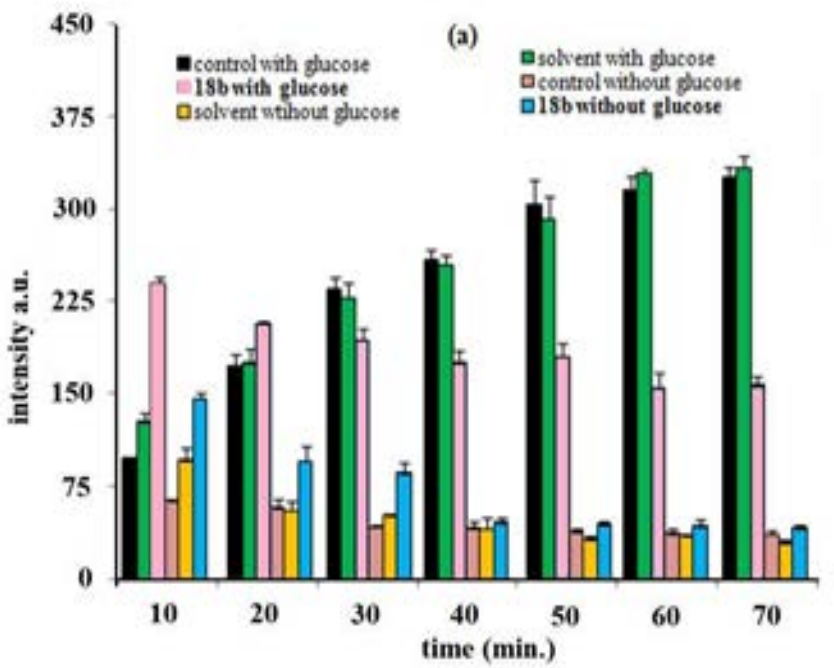

(b)

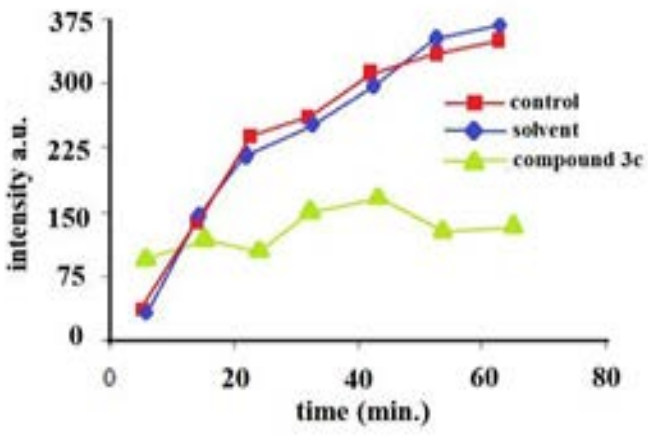

Figure 10: (a) R6G efflux in the presence of compound 3c. (b) differentiation between active and passive efflux. 


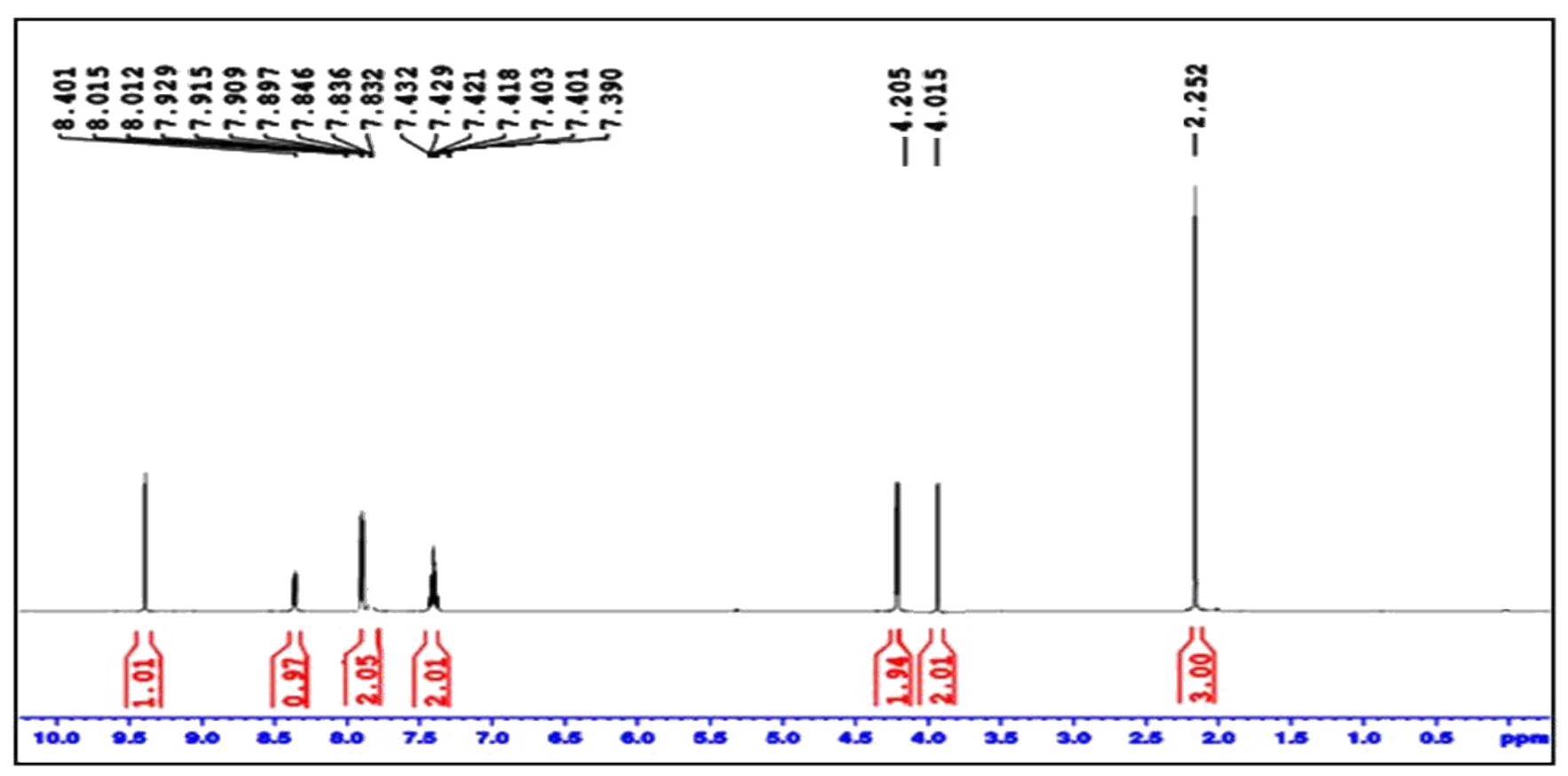

Figure 11: ${ }^{1} \mathrm{H}$ NMR spectra of compound 3a.

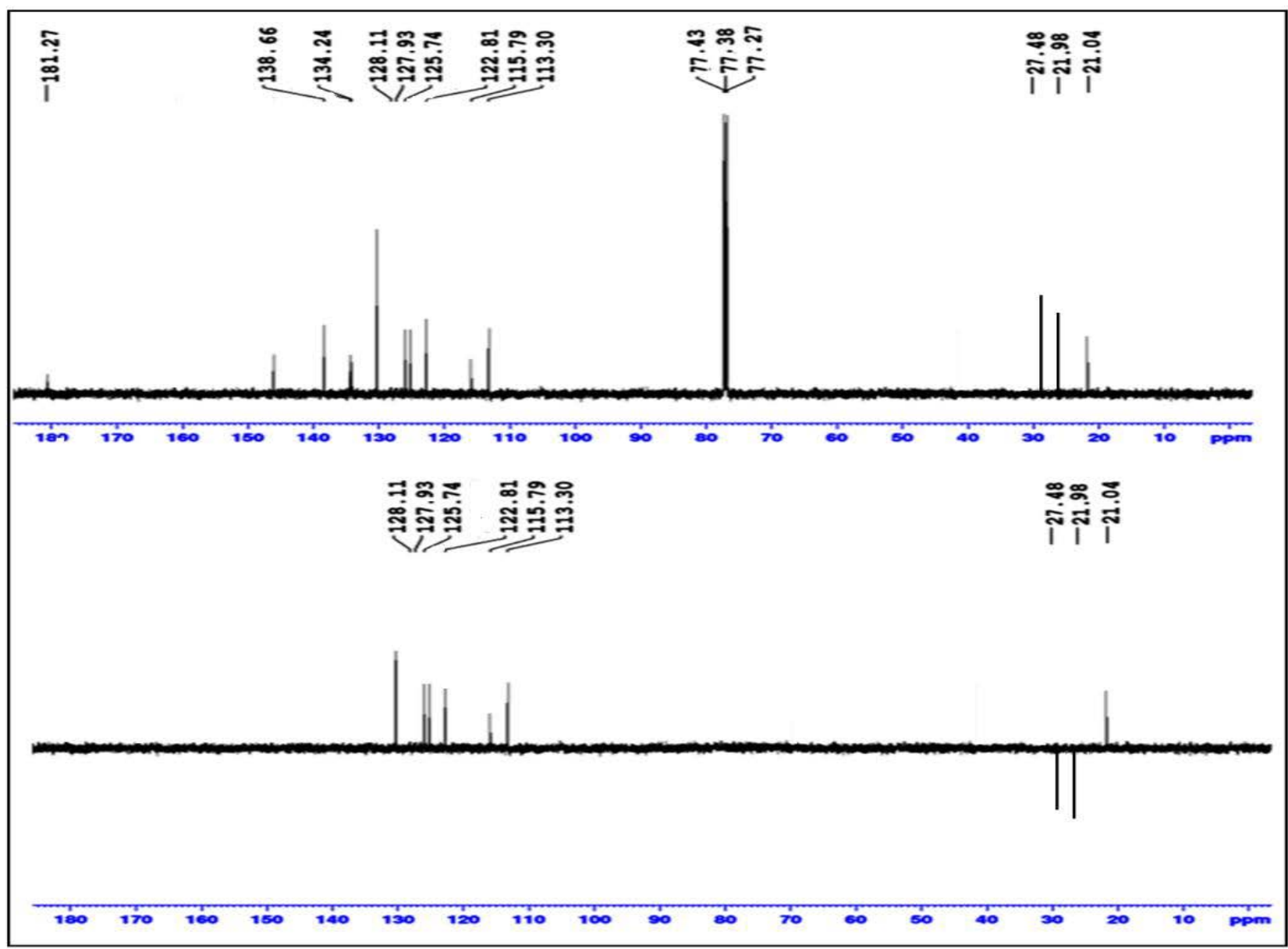

Figure 12: ${ }^{13} \mathrm{C} / \mathrm{DEPT}-135$ of compound $3 \mathrm{a}$ 


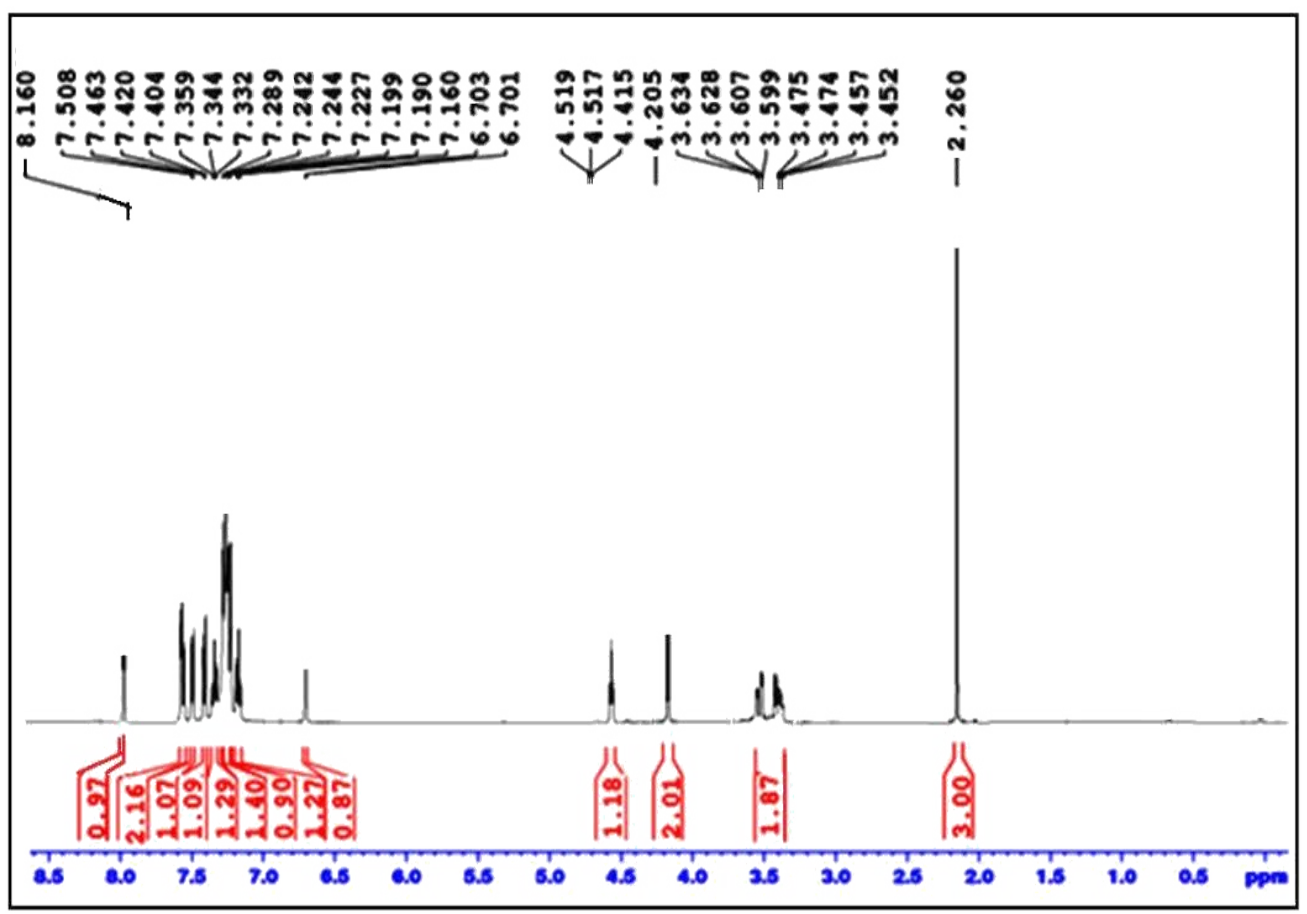

Figure 13: ${ }^{1} \mathrm{H}$ NMR spectra of compound $3 \mathrm{~b}$.

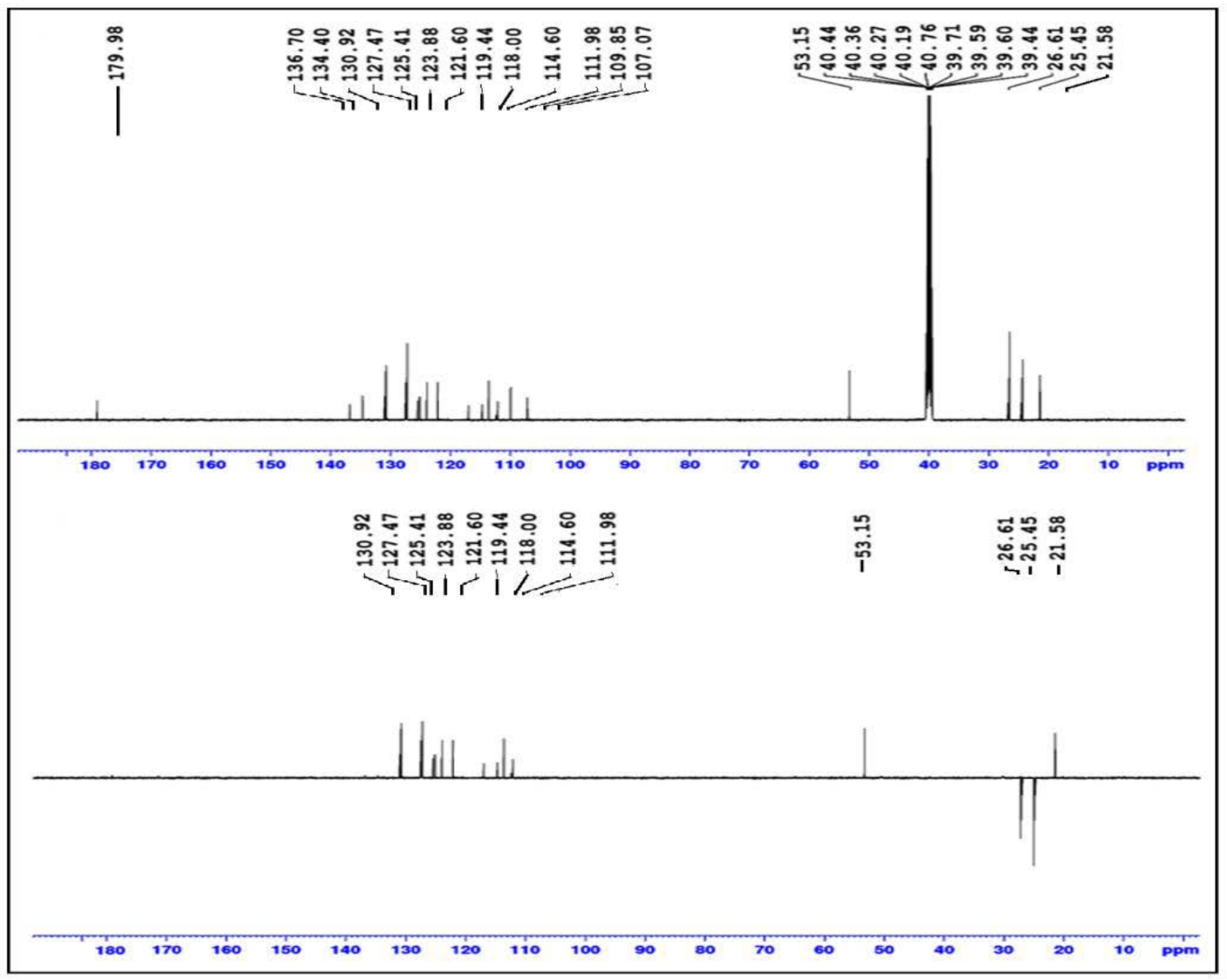

Figure 14: ${ }^{13} \mathrm{C} / \mathrm{DEPT}-135$ of $3 \mathrm{~b}$. 


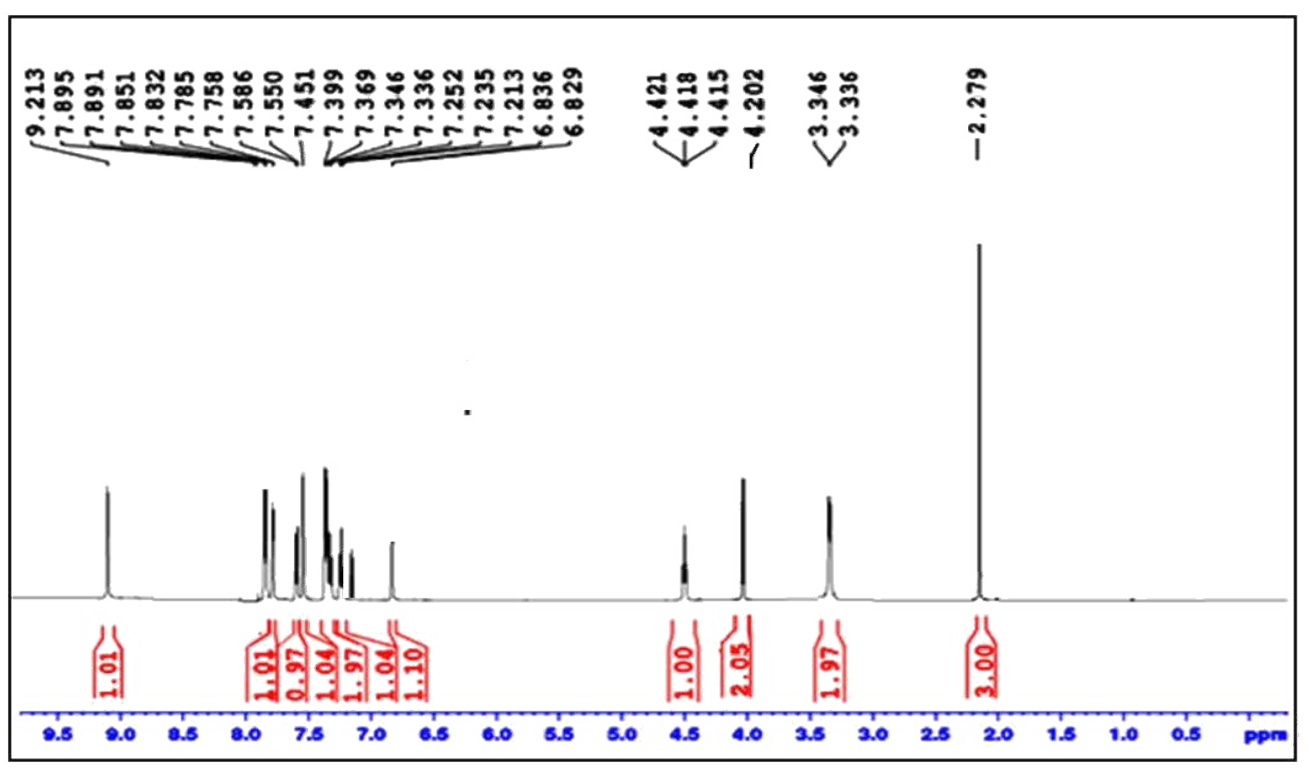

Figure 15: ${ }^{1} \mathrm{H}$ NMR of compound 3c.

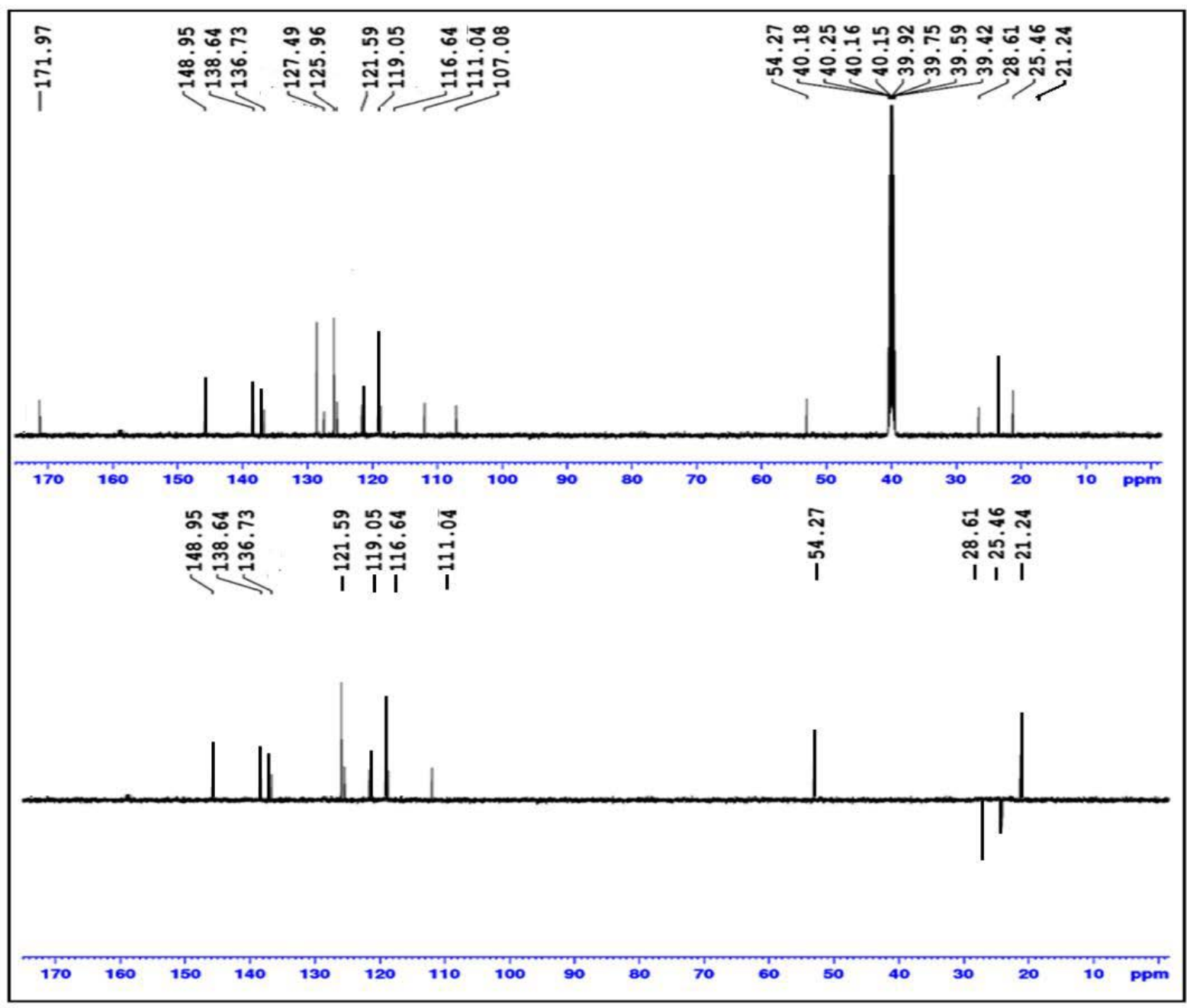

Figure 16: ${ }^{13} \mathrm{C} / \mathrm{DEPT}-135$ of compound 3c. 


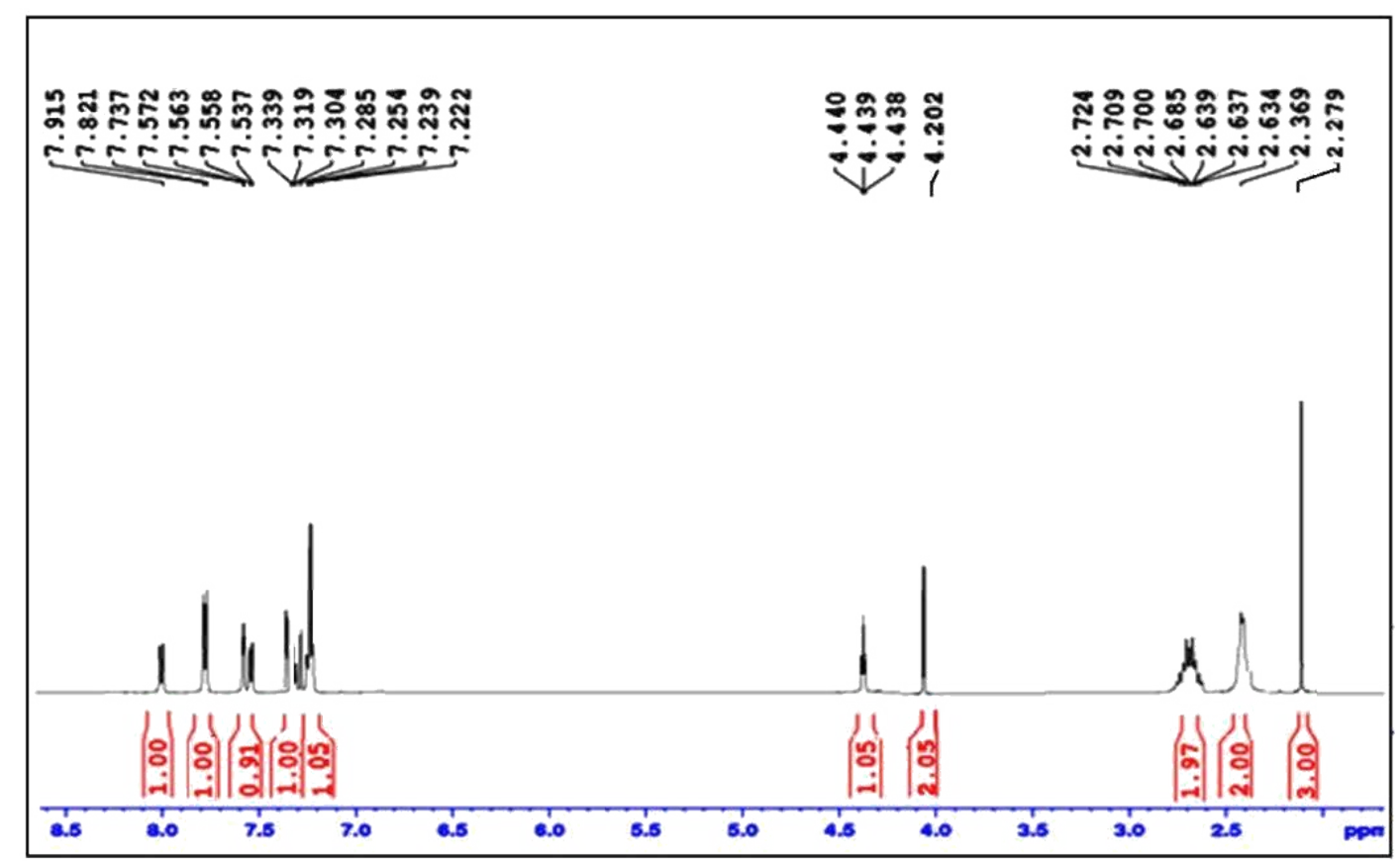

Figure 17: ${ }^{1} \mathrm{H}$ NMR spectra of compound $3 \mathrm{~d}$.

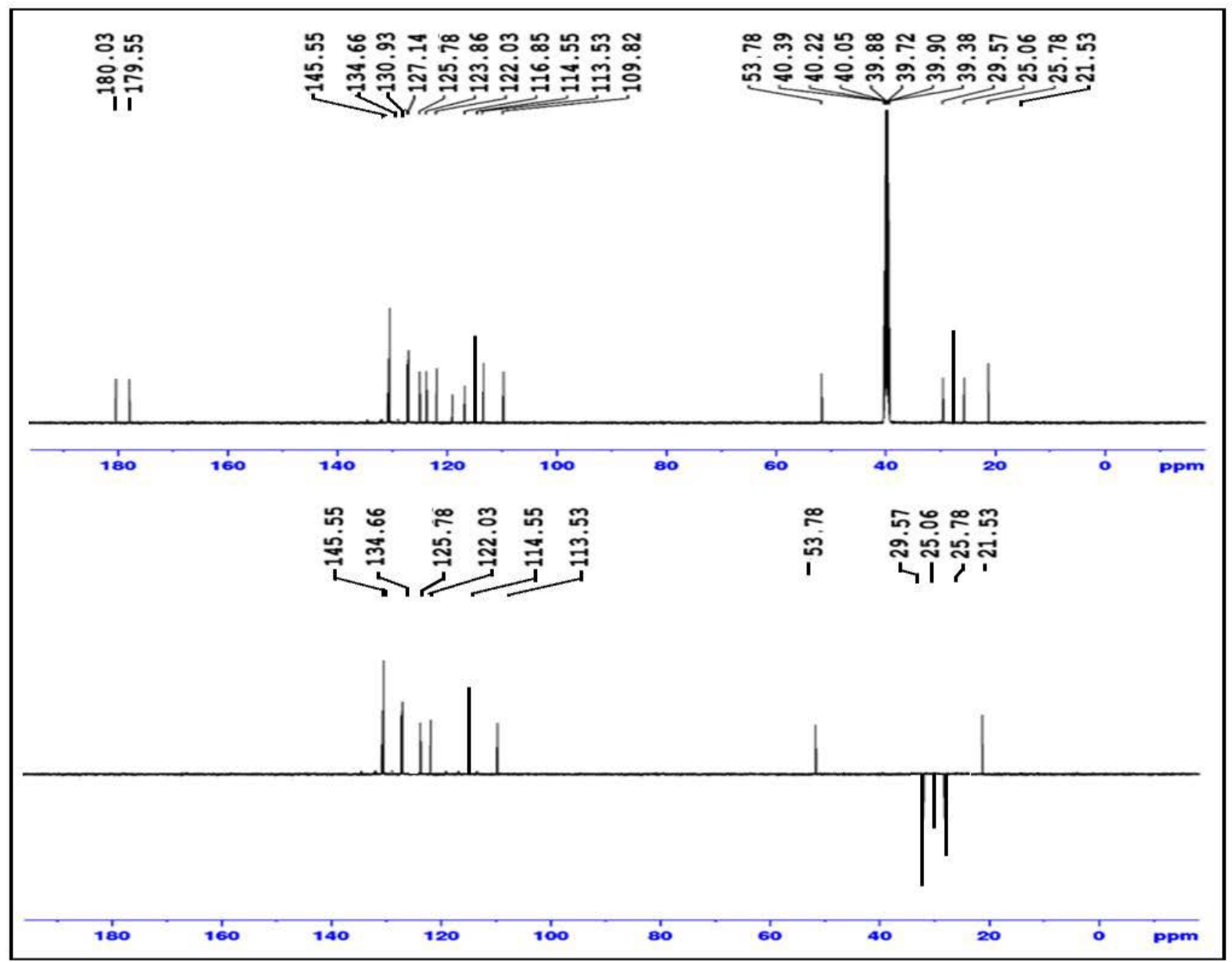

Figure 18: ${ }^{13} \mathrm{C} / \mathrm{DEPT}-135$ of compound $3 \mathrm{~d}$. 


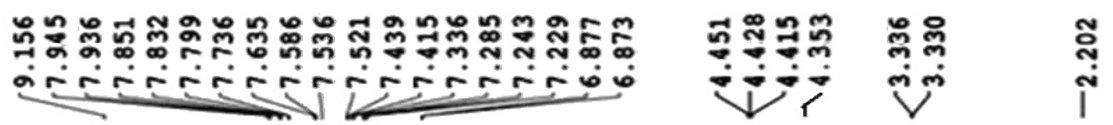

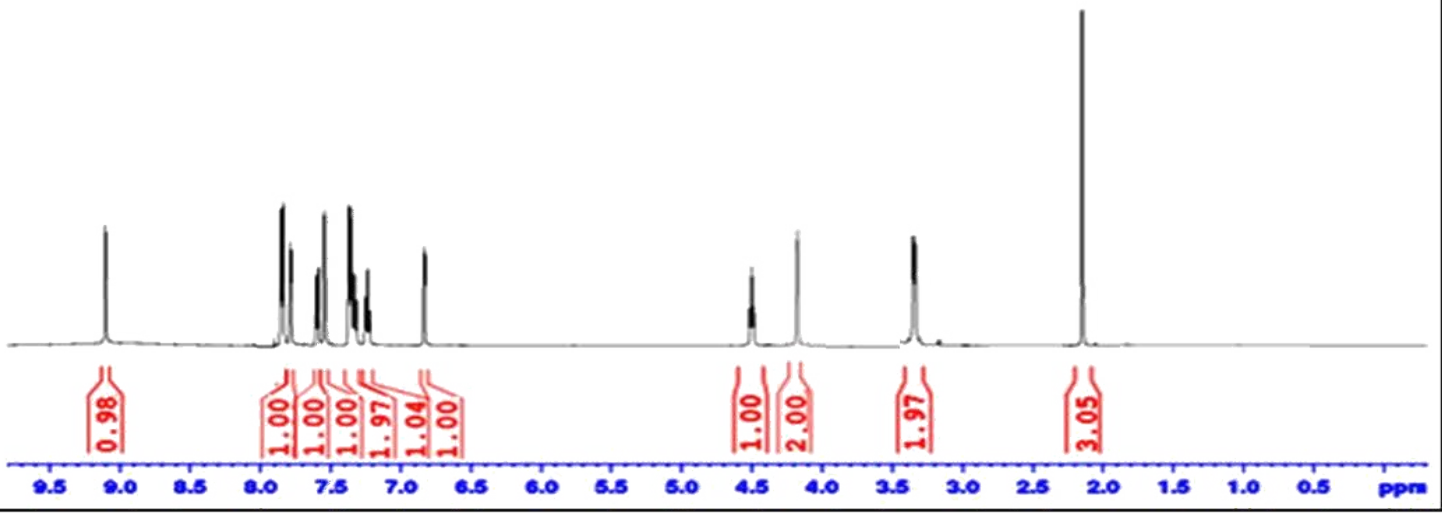

Figure 19: ${ }^{1} \mathrm{H}$ NMR spectra of compound $3 \mathrm{e}$.

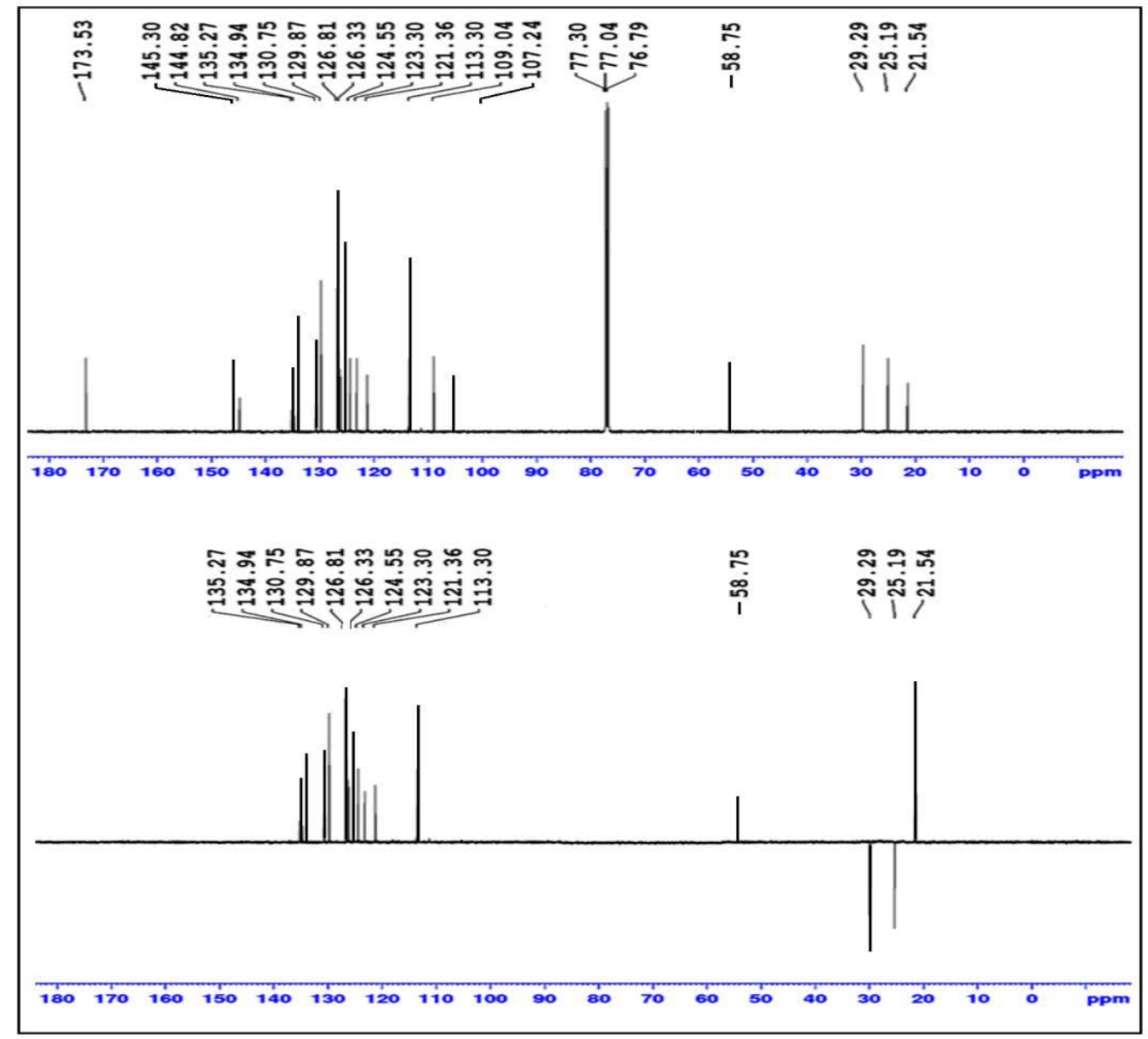

Figure $20:{ }^{13} \mathrm{C} / \mathrm{DEPT}-135$ of compound $3 \mathrm{e}$. 

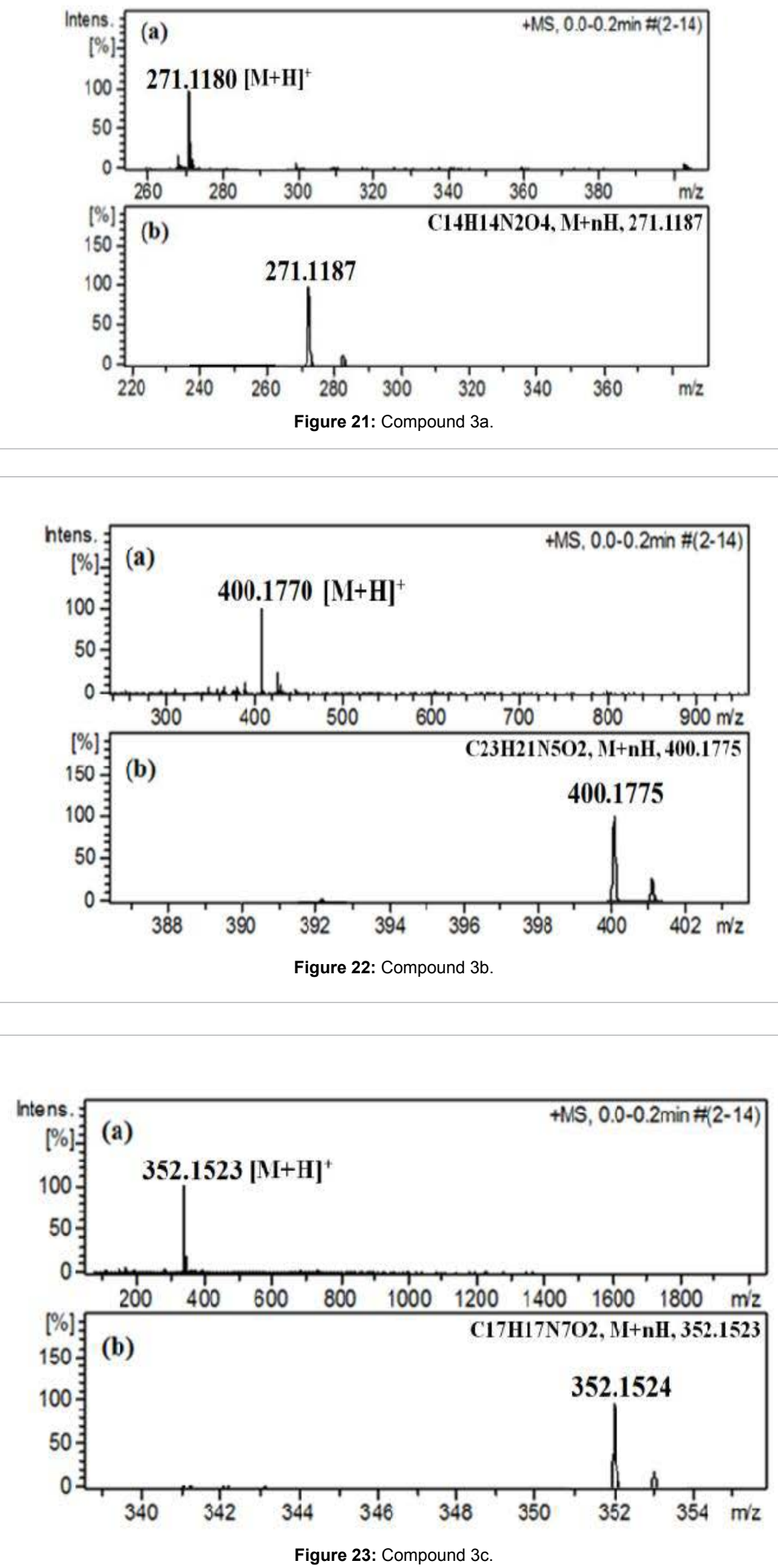

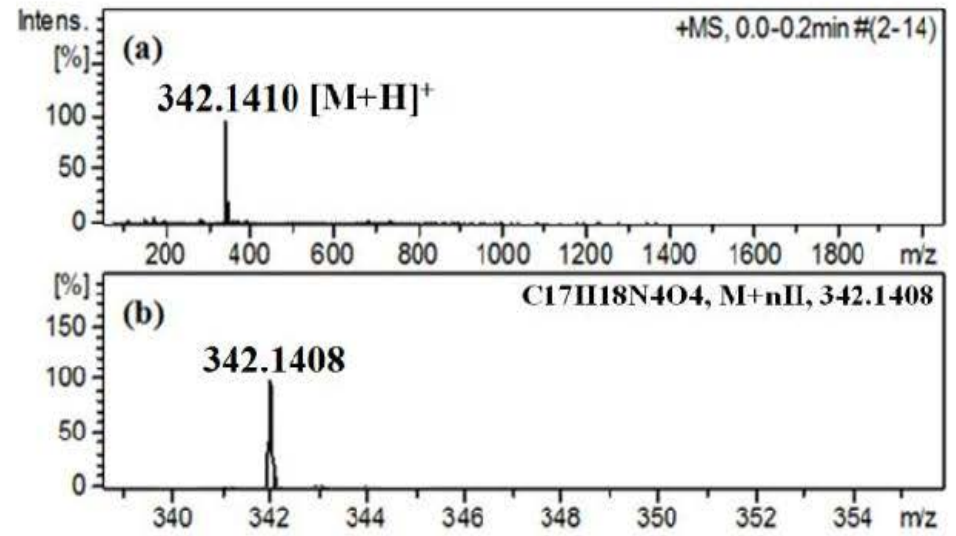

Figure 24: Compound 3d.
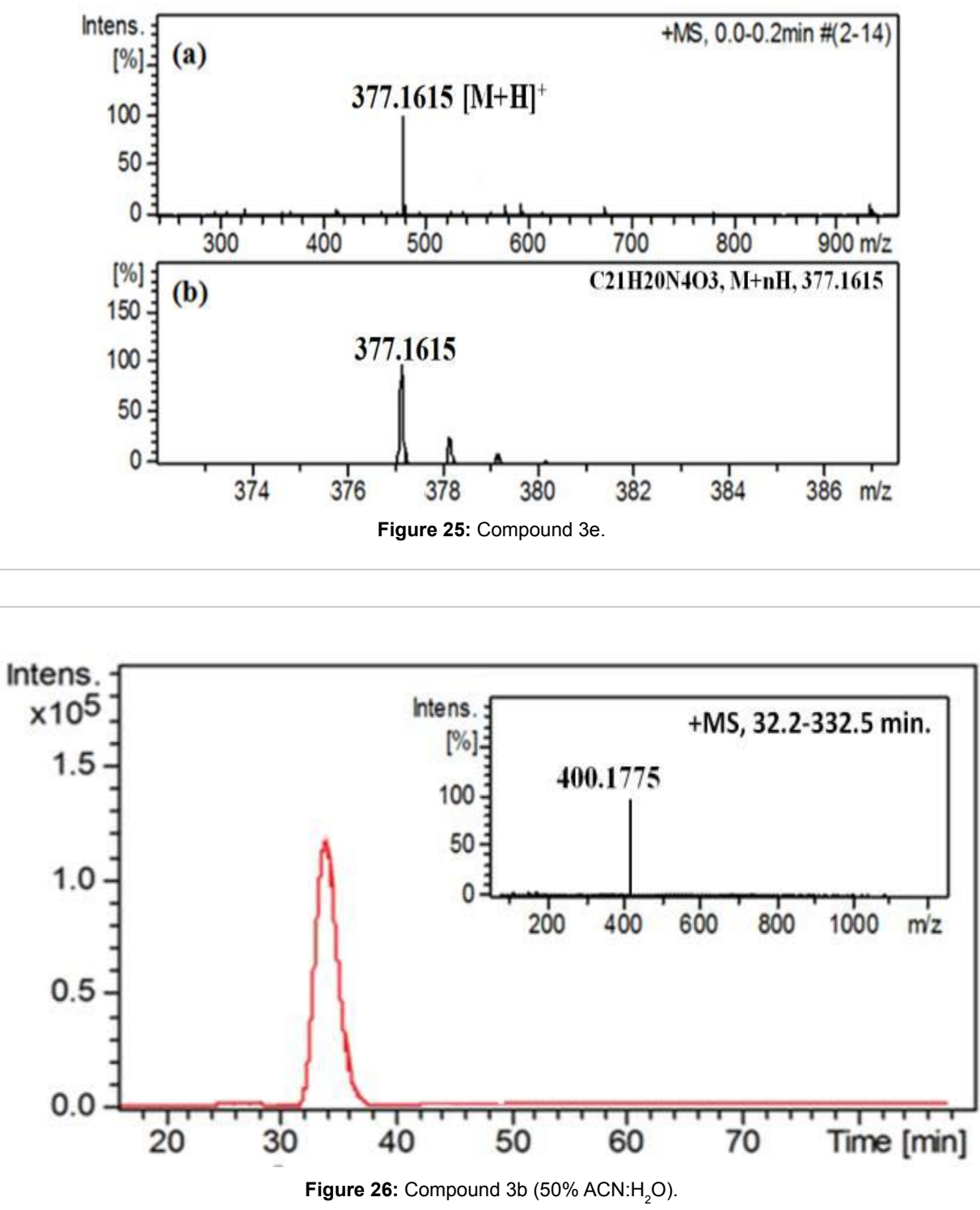
Citation: Prasher P (2016) Identification of Amino Acid Tethered Triazoles as Potential Antifungal Leads: Appraisal of their Mode of Action. Chem Sci J 7: 139. doi: 10.4172/2150-3494.1000139
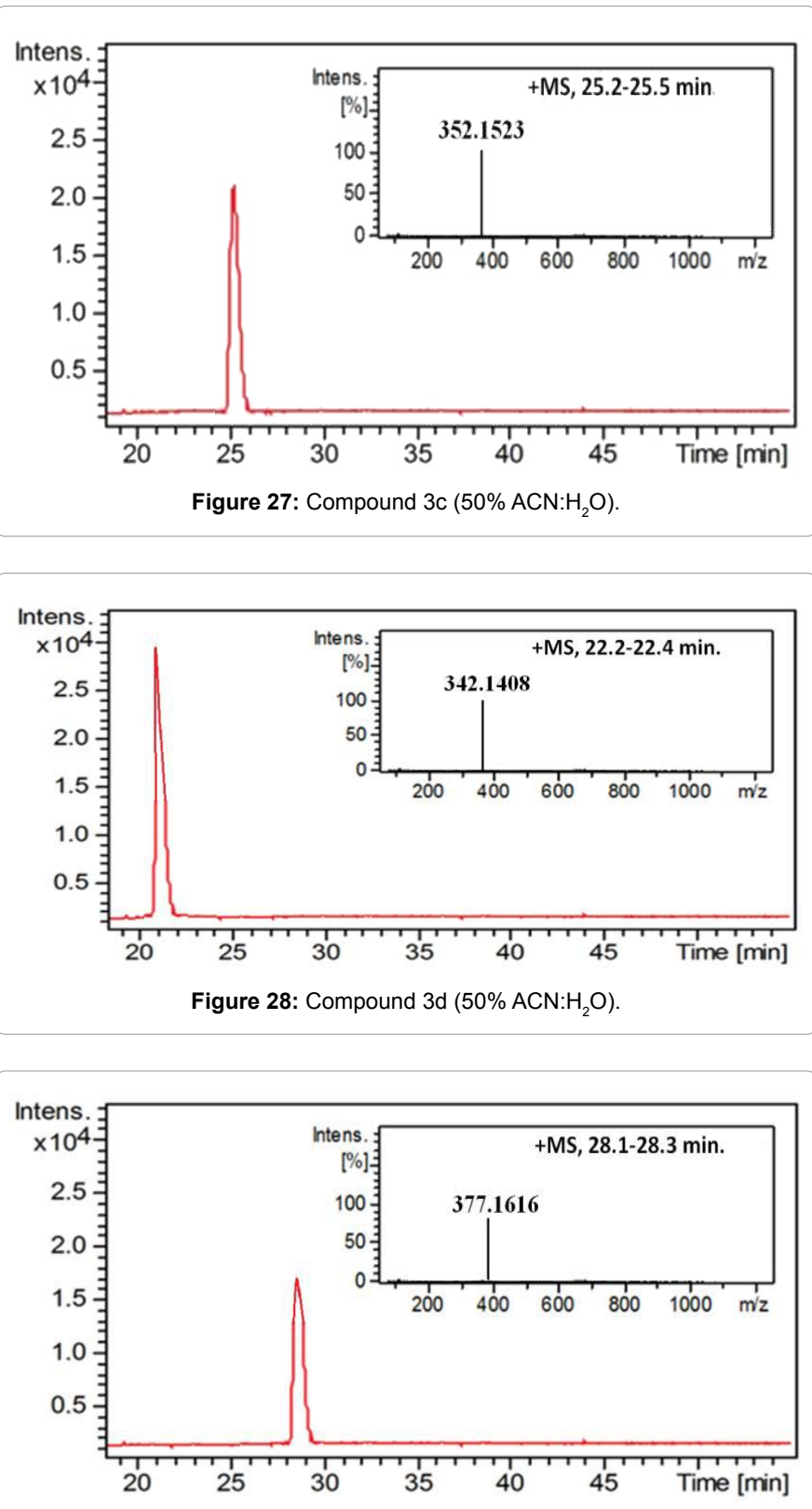

Figure 29: Compound 3e $\left(50 \% \mathrm{ACN}: \mathrm{H}_{2} \mathrm{O}\right)$. facility at Guru Nanak Dev University is highly acknowledged for characterization of the compounds. Special thanks to the faculty of biotechnology and pharmacology, Lovely Professional University for providing the fungal cultures and designing the in vivo experimental protocols and providing the requisite instrumentation for biological investigation of the compounds.

\section{References}

1. Ascioglu S, Rex HJ, Bennett JE, Bille J, Crokaert F, et al. (2002) Defining opportunistic invasive fungal infections in immunocompromised patients with cancer and hematopoietic stem cell transplants: an international consensus. Clin Infect Dis 34: 7-14.

2. Brown GD, Denning DW, Gow NAR, Levitz SM, Netea MG, et al. (2012) Hidden killers: human fungal infections. Med Mycol 4: 1-9.

3. Brajtburg J, Powderly WG, Kobayashi GS, Medoff G (1990) Amphotericin B: current understanding of mechanisms of action. Antimicrob Agents Chemother 34: 83-88.

4. Bossche HV (1985) Biochemical Targets for Antifungal Azole Derivatives: Hypothesis on the Mode of Action. Curr Topics Med Mycol 1: 313-351.

5. Birnbaum JE (1990) Pharmacology of the allylamines. J Am Acad Dermato 23: 782-785.

6. Denning DW (2003) Echinocandin antifungal drugs. The Lancet 362: 1142 1151.

7. Pfaller MA (2012) Antifungal Drug Resistance: Mechanism, Epidemiology and Consequences for Treatment. Am J Medicine 125: 3-13.

8. Prasher $P$ (2016) Identification of triazole bridged amino acids appended indoles as dual inhibitors of 5-LOX and COX-2 enzymes. Int J Chem Tech Res 9: 453-465. 